\title{
Tarihi Yarımadada Unutulmuş Bir İsim ve ve Zamana Direnen Bir Mekân: Saka Baba Dergahı
}

\section{Öğr. Gör. İsmail Sabah ${ }^{1 *}$}

Gelis tarihi: 05.08.2019

Kabul tarihi: 28.08.2019

\section{Atıf bilgisi:}

IBAD Sosyal Bilimler Dergisi

Sayı: Özel Sayı Sayfa: 90-115

Yıl: 2019

This article was checked by inthial.net. Similarity Index $11 \%$.

1 Çanakkale Onsekiz Mart Üniversitesi, Bayramiç Meslek Yüksekokulu, Türkiye, ismailsabah@comu.edu.tr

ORCID ID 0000-0002-9530-049X

* Sorumlu yazar öz

Gelibolu Yarımadası her yıl milyonlarca insan tarafindan ziyaret edilen ve dolayısı ile gerek ulusal gerekse uluslararası toplum nazarında göz önünde olan bir alandır. Burayı ziyaret eden insanların büyük çoğunluğu her ne kadar şehitlikleri ve yabancı mezarları ziyaret amaçlı geliyor olsa da bu ziyaret esnasında, güzergâhnda yer alan tarihi yarımadanın diğer kültürel varlıkları hakkında da bilgi almaktadırlar. $\mathrm{Bu}$ nedenle tarihi yarımadadaki kültür varlıkları üzerine gerçekleştirilen çalışmalar, anlatıların sağlam temele oturtulması için büyük önem arz etmektedir. Ziyaret güzergâhında yer alan kültür varlıklarından biri de Saka Baba Dergâhı'dır. Bu çalıșma, tarihi Gelibolu Yarımadası'nda Kadir Baba ismiyle anılan ve bu çalıșma ile Saka Baba Dergâhı olduğu tespit edilen tekke hakkındaki tespit ve değerlendirmeleri içermesi bakımından analitik bir çalışmadır. Çalışma için literatür taraması yapılmış ve tekkedeki mezar taşlarında yer alan ifadeler ile Cumhurbaşkanlığı Osmanlı Arşivi'nden elde edilen döneme ait belgeler araştırmacı tarafindan günümüz Türkçesine aktarılmıştır. Çalıșma ile tekkenin bir Bektaşi tekkesi ve isminin "Saka Baba Dergâhı" olduğu tespit edilmiştir. Ayrıca 1826' da Bektaşiliğin yasaklanması sonrasında bir dönem Kadiriye Tarikatı idaresine geçtiği ve ilerleyen tarihlerde tekrardan Bektaşi Tekkesi olarak faaliyetine devam ettiği sonucuna ulaşılmıștır. Calışma ile tekkenin gerçek isminin literatüre geçmesi ve mezar taşlarının kataloglanarak kayıt altına alınması amaçlanmışıı.

Anahtar Kelimeler: Gelibolu Yarımadası, Kilitbahir, Saka Baba Dergâhı, Kadir Baba Tekkesi 


\section{A Forgotten Name in the Historic Peninsula and a Place Resisting Time: Saka Baba Dervish Lodge}

\section{Prelector Ismail Sabah ${ }^{\text {* }}$}

First received: 05.08.2019 Accepted: 28.08 .2019

\section{Citation:}

IBAD Journal of Social Sciences Issue: Special Issue Pages: 90-115 Year: 2019

This article was checked by intihal.net. Similarity Index $11 \%$.

1 Çanakkale Onsekiz Mart University, Bayramiç Vocational School, Turkey, ismailsabah@comu.edu.tr

ORCID ID 0000-0002-9530-049X

* Corresponding Author

\begin{abstract}
The Gallipoli Peninsula is visited by millions of people every year and thus considered prominent both by national and international society. Although most of the people come to the peninsula to visit the martyrs and the foreign graves, they also get information about the other cultural assets of the historical peninsula on the route. For this reason, the studies carried out on cultural assets in the historical peninsula are of great importance for the establishment of a sound basis. One of the cultural assets in the itinerary is Saka Baba Dergâhı, a Dervish lodge. This study is an analytical study, which presents assessments and findings about the lodge in the Gallipoli Peninsula called Kadir Baba but found to be Saka Baba Dergâhı in this study. The relevant literature review was performed; the statements engraved on the gravestones in the lodge as well as the documents of the period obtained from the Ottoman Archives of the Prime Ministry were translated into Turkish by the researcher. It was determined that the lodge was a Bektashi lodge and its name is Saka Baba Dervish Lodge. The further study shows that the lodge was once governed by Kadiriye Tarikatı (Cult) for a while after the prohibition of Bektashism in 1826 and started to serve again as Bektaşi Tekkesi at a later date. The purpose of this study is to introduce the real name of the lodge to the literature and to list and record the gravestones. The aim of the study is to pass the real name of the lodge to the literature and to record the tombstones by categorizing them.
\end{abstract}

Keywords: Gallipoli Peninsula, Kilitbahir, Saka Baba Dergâhı, Kadir Baba Tekkesi 


\section{GíRIŞ}

Gelibolu Yarımadası, Türk tarihinde birçok önemli olaya ev sahipliği yapmıș bir coğrafyadır. Osmanlı Türklerinin Rumeli'ye geçişleri bu yarımadadan gerçekleştiği gibi Türkleri Avrupa'dan çıkarmak isteyen düşünceler de, bu yarımada da 1915'teki Çanakkale Muharebeleri sonucunda hayal kırklığına uğratılmıştır. Geçmişin hatıraları, her yıl milyonlarca insanı Gelibolu Yarımadası'na çekmekte ve Çanakkale şehitlikleri ile yabancı mezarlıklar ziyaret edilmektedir. Uluslararası alanda göz önünde bir alan olan tarihi yarımadada anlatıların sağlam temele oturması için bilimsel çalışmalara ihtiyaç olduğu gerçektir. Çanakkale şehitlikleri güzergâhında olan "Saka Baba Dergâhı" hakkındaki araştırma bu nedenle önemli bir mesele olarak karşımızda durmaktaydı. Mevkii olarak Kilitbahir Köyü'nden Çanakkale Şehitler Abidesi'ne giden yol güzergâhında ve yine Çanakkale Muharebelerinde faal olarak kullanılan Yıılız Tabyası'nın önündeki yamaçta bulunan Saka Baba Dergâhı ${ }^{1}$ hakkında ne yazık ki literatürde yeterli bilgi bulunmamaktadır. $\mathrm{Bu}$ nedenle tekke hakkındaki araştırmalara ihtiyaç duyulmaktadır.

\section{TÜRKLERIN RUMELI'YE GEÇiŞi VE TEKKELERIN KURULUŞU}

Osmanlıların, ilk defa 1353'te Rumeli'ye geçtiği hemen hemen her kitapta yer alan bir husustur. Ancak 1353'ten önce Osmanlı askerleri, defalarca Rumeli'ye geçmiş ve burada faaliyet göstermişlerdir (Afyoncu, 2005, s. 1). Orhan'ın bu Uc'ta yerleşen oğlu Süleyman Paşa (ölümü 1357), Kantakuzenos'un müttefiki olarak defalarca Trakya'ya geçmiştir ve sonunda 1352'de Kantakuzenos'un kışlamak için ona teslim ettiği Cinbi Kalesi'nde yerleșip kaldı. Gelibolu Yarımadası'nda en önemli stratejik noktayı, Bolayır'ı zapt etti ve Anadolu'dan süratle geçirdiği Türkmenleri, güneye ve batıya doğru akın yapmak üzere örgütledi. İki yıl sonra, 1354 yılı Mart ayında şiddetli bir yer sarsıntısında surları yıkılan önemli Gelibolu Kalesi'ni ele geçirdi. Böylece Balkan fütuhatı başlamış oldu (İnalcık, 2017, s. 12). Duraklamak buradaki gaziler için yok olmayı beklemek demekti. Yayılmak ve kuvvetlenmek, her gün Anadolu'dan ahiler ve dervişlerle beraber gelmekte olan göçmenlere yeni yurtlar açmak bu yeni ülkede tutunmanın ve yaşamanın tek yoluydu (Afyoncu, 2005, s. 4). Ahilerin ve dervişlerin zaviyeleri ile çiftlikler yeni Müslüman köylerin çekirdeğini teşkil etti (Afyoncu, 2005, s. 6). Osmanlı Türklerinin Rumeli’ye geçişleri ile Bektaşîliğin de bölgede faaliyetlerinin arttı̆̆ı bilinmektedir.

Hacı Bektâş-1 Velî (ö. 669/1270-71)'ye nisbet edilen ve XIII. Asırda Anadolu topraklarında tesis edilen Bektâş̂liğin, Gelibolu'daki faaliyetleri Rumeli'nin fethinden öncesine dayanmaktadır. Bektaşi dervişleri gerek fetihten önce gerek fetihten sonra kurmuş olukları tekkelerle bölgenin Türkleşmesi ve İslamlaşması yolunda çaba harcamışlardır... ... bu Bektaşi tekkelerinden bir kısmı bakımsızlık nedeniyle yıkılırken, bir kısmı da 1826'da Bektaşiliğin yasaklanmasıyla diğer tarikatların hizmetine girmiş̦tir (Şimşek, 2007, s. 283-284).

Çanakkale'nin erken dönem Bektaşîliği hakkında bilgi vermek oldukça güçtür. Anadolu'nun İslamlaşma süreci ve Balkanlara Türklerin geçişi, bu toprakların Müslümanlarla tanışması önemli ölçüde Bektaşilikle bağlantılı bir durumdur (Yönem, 2015, s. 76). Çanakkale ve özellikle Gelibolu bu tarikatların yerleşimi, gelişimi ve geçişini sağlayacak stratejik konumuyla Anadolu tasavvuf ortamına önemli katkıda bulunmuştur. Anadolu'nun pek çok bölgesinde faaliyet gösteren Ahîlik, Bektaşilik, Mevlevîlik, Rifâ̂lik, Nakşibendîlik, Sünbüliye, Halvetîlik, Kâdirîlik, Bayramîlik, Calvetîlik, Sa'dîlik gibi çeşitli tarikatların Çanakkale'ye kadar taşınması ve Balkanlar'a doğru yayılması dikkate değerdir (Altıer, 2018, s. 104-105).

$\mathrm{Bu}$ nedenle Gelibolu Yarımadası, farklı tarikatlara ev sahipliği yapan ve birçok tekkeyi barındıran bir coğrafya olmuştur. Şuan tarihi alan dediğimiz Çanakkale Savaşları Gelibolu Tarihi Alan Başkanlığı'nın sorumluluk sahasında ve sorumluluk sahası sınırlarına yakın bölgede kalan birçok tekke ve türbe bulunmaktadır. Akbaş Baba Tekkesi, Cahidî Sultan Türbesi, Ece Baba Türbesi, Beşyol Köyü sınırlarında Tekke Tepe'de bir tekke kalıntısı, Büyük Kemikli Burnu'nda yer alan Gazi Baba mezarı gibi alanlar tarihi yarımadanın sahip olduğu zenginlikler arasındadır.

\footnotetext{
${ }^{1}$ Konum için bkz. Ek 1.
} 


\section{SAKA BABA DERGÂHI}

Çalışmamıza konu olan Saka Baba Dergâhı da ${ }^{2}$ bu tekkelerden biridir. Söz konusu tekke Gelibolu Yarımadası'nda Eceabat ilçesine bağlı Kilitbahir Köyü sınırlarında ${ }^{3}$ bulunmaktadır. Tekkenin ne zaman faaliyete başladığına dair bir kaynak bulunmuyor olsa da ismini tekkeye veren Saka Baba'nın mezar taşındaki ölüm tarihi, en azından tekkenin ne zamandan beri ibadete açık olduğuna dair ipucu vermektedir. Saka Baba'nın mezar taşında ise aşağıdaki ifadeler yer almaktadır.

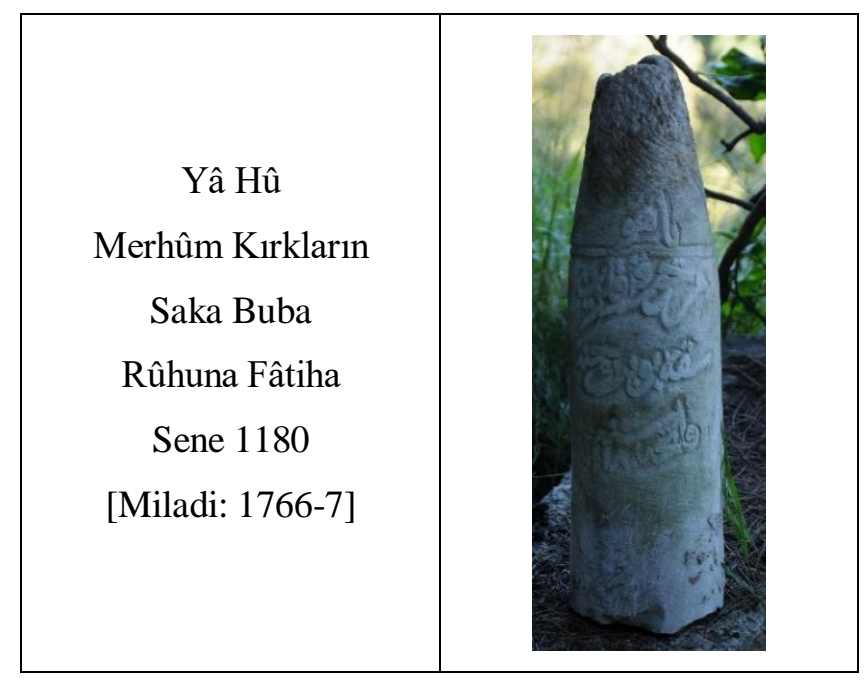

Saka Baba'nın vefat tarihinden hareketle tekkenin 18. yüzyıl ortalarından itibaren faaliyette olduğu yorumu çıkarılabilmektedir.

Tekke ile ilgili diğer önemli bir konu ve bu çalışmada yanttlanmaya çalışılan soru ise zaman içerisinde Saka Baba isminin unutularak "Kadir Baba Tekkesi" olarak anılagelmesidir. Literatürde söz konusu tekke bu isimle zikredilmektedir. ${ }^{4} \mathrm{Bu}$ sorunun kaynağına dair maalesef bir belge bulunmamaktadır. Tekke isminden Kadir Baba Tekkesi olarak bahseden kişiler arasında 1915'te Çanakkale Muharebelerine iştirak eden Münim Mustafa'da (Pekselek) vardır. Münim Mustafa'nın hatıratı sayesinde 1915'te Çanakkale Muharebeleri esnasında askerlerin bu tekkeye uğradıklarını ve dinlenip, yemek yediklerini ögrenmekteyiz. Münim Mustafa hatıratının 8 Kasım 1915 gününe denk gelen sayfasında:

Alayın ziyafeti Kadir Dede denilen çamlık içinde yapılması mukarrerdi. Ale's-sabah oraya gitmiştim. Öyleye kadar her şey hazırlanmıştı. Alay zabitanı, müteakiben firka kumandanı erkân-ı harbiyesiyle geldiler. Bulunduğumuz yer yüksek ve çamlar içinde olduğundan denize karşı manzarası fevkalade güzeldi. Hakikaten Avrupa'da bulunduğum sırada orada bile eşine tesadüf edemedim. Bu güzel manzarayı herkes seyrettikçe bir inşirah hissediyordu (Pekselek, 2018, s. 133).

Münim Mustafa bu tekkede, görev yaptığı 30. Alay subaylarına harp madalyası dağıtılırken bir de fotoğraf çekmiştir. Bu fotoğraf ${ }^{5}$ ve hatırat sayesinde 1915 senesinde tekkedeki bina yapılarından en azından birinin sağlam bir şekilde ayakta durduğunu görebilmekteyiz.

\footnotetext{
2 Tekke fotoğrafi için bkz. EK 2

${ }^{3}$ Köye yaklaşık 2 km mesafe, Çanakkale Boğazı'na nazır bir yamaçtadır.

4 “...Aynı kaynă̆a göre bir dĭ̆er tekke de Kadir Baba Tekkesi’dir...” (Yönem, 2015, s. 82), ve bkz. (Özel, 1991, s. 168).

${ }^{5}$ Münim Mustafa Pekselek'in 1915'te çektiği fotoğraf için bkz. EK 3
} 
Kadir Baba Tekkesi ismiyle maruf Saka Baba Dergâhı'ndan bahseden diğer bir isim ise Orhan Cezmi Tuncer'dir. Tuncer, “Anadolu Kümbetleri 2 Beylikler ve Osmanlı Dönemi” isimli eserinde "Kadir Baba Türbesi” başlı̆̆ adı altında şu bilgileri vermektedir:

Havuzlar Mevkii'ne giderken, dă̆a doğru tırmanılan patikada, yüksekçe bir tepede, çam ormanlarının başladı̆̆ yerde, yapı topluluğunu V.G.M. elemanlarından Nazife Kurtman duymus ve yerinde incelemişti. Lütfedip bana bu bilgileri verdiler. Buna göre ayakta kalan tek yapının türbe olabileceği belirtiliyor. Güney ve batısında küçük dikdörtgen pencereler ${ }^{6}$, güney yönde kapatılmış 2 pencere ve ikisinin de kemer alınlı̆̆ında kuş köşkü var. Doğu cephesinin sağ (kuzey) ucundan içeri girilir. Batı duvarında pencerenin yanında $20 \times 20 \mathrm{~cm}$ 'lik küçük ${ }^{7}$ doğu duvarinda $30 \times 80 \mathrm{~cm}^{\prime} l i k$ orta boy birer dolap ${ }^{8}$ var. Kitlenin doğusunda haziresi yer alıyor. Büyük çınar ve 2 servi arasında kalan türbesi ise içte sekizgen yıldız tavanl, ahşap bağdadi sivall. Üzerinde mavi renkli badana vurulmuş ${ }^{9}$ ve bezenmiş. Bugün çok yıpranmış ve pek çok yerinde sıvalar dökülmüsstür. Üst dış örtüsünün kare piramit olması şansı fazladır. Tekke de böyle olup alaturka kiremitle kaplıdır ${ }^{10}$... dedikten sonra Ramazan Eren'den alıntıla devam ediyor. ...etrafi pınar ormanı ve çam ă̆açlarıyla çevrili, tabii güzelliğinin tasviri mümkün olamayacak kadar harika bir yerde bulunmaktadır. Bugün birçok kalıntısı mevcut. Tekkenin içinde iki mezar bulunuyor. Buranın yan duvarları sağlam fakat üstü çökmüs vaziyette bulunuyor. 30-35 sene öncesine kadar ziyaretçisi eksik değildi. Özellikle Hızır-illyas günlerinde gelinir, dini merasimler icra edilir ve Muharrem ayında aşure pişirilir, yenilir, içilir ve mevlitler okunurdu. Şuanda her şeyiyle ölüme terkedilmiş vaziyete bulunuyor. Hülasa yerin harikalı̆̆, tarihi çınar ağaçları, ormanların içinde Osmanlıca yazılı mezar taşları hem kültürümüz hem de insan ruhunu dinlendirmesi bakımından bu kadar harika bir yerin kendi haline terk edilmesi üzücü bulunuyor (Tuncer, 1991, s. 138).

Orhan Cezmi Tuncer'in atıfta bulunduğu Nazife Kurtman ise tekke hakkındaki tespitlerini şu şekilde anlatmaktadir:

Kadir Baba Tekkesi: Kilitbahir ile Havuzlar Mesire Yeri arasinda, eski Yıldız Tabyası'nin denize bakan yüzü tarafindadır. Şu anda harabe halinde bulunan tekkeye ulaşmak bizim içinde zor oldu. Hatta ekibimizden yapıya kadar ulaşamayıp geri dönen arkadaşlarımız oldu. Boğazın güney ucuna hakim bir tepede bulunan tekkenin çevresinde birkaç yapı kalıntısı, mezarlar ve bir havuz vardır. Yapıllı̧ tarihi bilinmeyen yapı kare planl, sekizgen tavanlı ve piramidal çatılıdır (Kurtman, 1991, s. 172).

İki kaynaktan elde ettiğimiz bilgileri derleyecek olursak söz konusu tekkede:

1 -) İçinde iki mezar olduğu ifade edilen türbe binası,

2 -) Türbe binasının yanında hazire,

3 -) Tekke Binas1,

4 -) Bir havuz

\footnotetext{
${ }^{6}$ Türbenin güney cephesinde yer alan pencere, yaptığımız ölçümlerde iç derinlik: $52 \mathrm{~cm}$, en: $90 \mathrm{~cm}$ olarak ölçülmüş, boy uzunluğu ise toprak yığıntısından ölçülememiştir. Batı duvarında yer alan pencerenin iç derinliği 50 cm, eni 56,5 ve boyu ise 96,5 olarak ölçülmüsşür. Burada şunu da belirtmek gerekir ki, sıva döküntüleri ve toprak yığınları nedeniyle yaptığımız ölçümler yaklaşık sonuç vermektedir. Bkz. EK 4, 5 ve 6.

${ }^{7}$ Bu dolap bizim yaptı̆̆ımız ölçümlerde iç derinlik: $28 \mathrm{~cm}$, en: $23,5 \mathrm{~cm}$, boy $39,5 \mathrm{~cm}$ olarak ölçülmüştür. Bkz. EK 5 ve 6.

${ }^{8}$ Doğu duvarında olduğu bahsedilen dolap, yıkıntıdan dolayı günümüzde net olarak seçilememektedir. Türbenin iç doğu duvarı için bkz. EK 7.

${ }^{9}$ Bahsedilen mavi badana izleri için bkz. EK 4 ve 5 .

${ }^{10}$ Türbenin çatısı yıkık durumda olsa da duvarların üstünde kiremitler görülebilmektedir. Bkz. EK 8.
} 
bulunduğu ifade edilmektedir. İlk maddeden başlayacak olursak, türbe ve içinde iki mezar olduğu ifade edilen bina yapısı hala ayaktadır ama çatısı çökmüş ve duvarları da yıkılmak üzeredir. ${ }^{11}$ Ayrıca içinde olduğu bahsedilen iki mezar şuan bulunmamaktadır. Maalesef bahsedilen bu iki mezar taşının akıbeti hakkında da bir bilgi bulunmamaktadır. Türbe binasının içi kaçak kazılar nedeniyle talan edilmiş durumdadır. Farklı yıllarda çekilen fotoğraflarda türbe içinde görülen toprak yığınları, türbenin iç kısmının defalarca kazıldığını göstermektedir. Bu durum aslında burada iki mezar olduğunu da doğrulayan ipucu olarak algılanmaktadır. Şöyle ki, bu kazıları gerçekleştiren kişilerin söz konusu mezarlarda kıymetli eşya bulma amacıyla burayı kazmış olma olasılıkları yüksektir. Ayrıca bu iki kıymetli çalışma sayesinde bu yapının türbe binası olduğu da anlaşılmaktadır. Öte yandan kaynaklarda bahsedilen, türbe yapısının içindeki mavi renkli badana ve bezemelerden izler de yukarıda bahsedildiği üzere hala görülebilmektedir. Söz konusu yapı içinde, 2011 yılında gerçekleştirilen yüzey araştırmasında tespit edilip fotoğraflanan ve Hz. Ali'nin kılıcı olan Zülfikar'a benzetilen bir süsleme ve bu süslemenin içinde de tahribattan dolayı okuyamadığımız Arapça veya Osmanlıca yazılar mevcut idi. ${ }^{12}$ Ne yazık ki türbenin batı duvarında, bu süslemenin olduğu kısımdaki sıvaların dökülmüş olması ile bu iz kaybolmuştur.

İkinci madde de türbe binasının yanında ki hazireden bahsedilmiştir. Ancak hazirede mevcut mezar taşlarının sayısından veya burada medfûn bulunan kişilerin kimliklerinden bahsedilmemiştir. Bu konuya, günümüzde mevcut mezar taşları üzerinde yaptığımız çalışma ile aşağıda değinilmiştir.

Üçüncü madde de belirtilen bir tekke binasının varlığı, ilgili kaynakların satır aralarından anlaşılmıştır. Ancak günümüzde türbe yapısının haricinde ayakta kalan bir bina yapısı bulunmamaktadır. Sadece türbe binasının arkasında temelleri gözüken ve yıkık durumda olan bir bina kompleksi bulunmaktadır ${ }^{13}$. Bahsedilen tekke binasının burası olduğu iddia edilmektedir. Dördüncü madde de ise tekkede bir havuzun varlığından söz edilmektedir. Ancak havuz yapısı günümüzde mevcut değildir.

Tekke'nin ismi konusuna değinecek olursak, "Kadir" ismiyle anılması olasılıklarından biridir ve tekkenin bir zamanlar Kadir isminde birinin idaresinde olmuş olabileceğidir. Olasılık diyoruz çünkü bu isme dair bir kaynak tüm araştırmalarımıza rağmen bulunamamıştır. Türbe yapısının içinde var olduğu düşünülen iki mezardan birinin söz konusu kişiye ait olma olasıllğı da bulunmaktadır.

Tekkede zamana direnip kaybolmayan veya çalınmayıp varlığını muhafaza edebilmiş mezar taşlarını incelediğimizde "Kadir" isminde birinin olmadığ 1 görülmektedir. Aslında tekkenin haziresi de kaçak kazılar yüzünden tahrip olmuş durumdadır. ${ }^{14} \mathrm{Bu}$ isimde birinin mezar taşı, eğer hazirede ise zamanla kaybolmuş veya çalınmış olması muhtemeldir. Nitekim Saka Baba'nın da mezar taşı 2011 senesinde Eceabat Kaymakamlığı için gerçekleştirilen yüzey araştırmasında tespit edilip fotoğraflanmışken, 2017 senesinde Çanakkale Savaşları Gelibolu Tarihi Alan Başkanlığı adına gerçekleştirilen yüzey araştırmasında tespit edilememiştir. Ne yazık ki tekkeye ismini veren kişinin mezar taşı kaybolmuş veya çalınmıştır. Bu nedenle çalışmadaki amaçlardan bir diğeri de burada medfûn bulunan kişilerin isimlerinin tarihe bir not olarak düşürülmesi olmuştur. Böylelikle kaybolmaları veya çalınmaları halinde isimlerinin unutulup, yok olmasının önüne geçilmek istenmiştir. Şöyle ki, aşağıda sunduğumuz tablo incelendiğinde vefat tarihleri 1766-7 - 1906-7 yılları arasında olan 14 kişiye ait mezar taşının tespit edildiği görülecektir. Bu sayının çok daha fazla olması gerektiği açıktır.

Bu çalışmanın ilk amacı, bahsedildiği üzere tekke isminin "Saka Baba Dergâhı" olarak literatüre geçmesidir. Cumhurbaşkanlığı'na bağlı Osmanlı Arşivi'nde yer alan ve zâviye-dâr tayiniyle ilgili bir belge de bu durum açıkça görülmektedir. Söz konusu belgede yer alan ifadeleri inceleyecek olursak:

Mâ'rûz-1 kullarıdır ki

Kilidü'l-bahr Kal'ası kurbinde vâki' e'izze-i kirâmdan Saka Baba nâm azîzin zâviyesinde ber-vech-i hasbî zâviye-dâr olan tarîk-i Bektâşiyândan Kabataşlı

\footnotetext{
${ }^{11}$ Bkz. EK 8.

122011 yılında tespit edilip fotoğraflanan süsleme için bkz. EK: 9, süsleme içindeki yazılar için bkz. EK: 10 ve şuan ki hali için bkz. EK: 5.

${ }^{13}$ Söz konusu kalıntılar için bkz. EK: 11

${ }^{14}$ Bkz. EK 12.
} 
Muhammed Baba bi-emr-illâhi Teâlâ fevt olub zâviye-i mezkûrede on beş seneden mütecâviz aşçıbaşılık hidmetiyle mukîm olan Mustafa Dede her vechile lâyık ve mahall-i müstahakk olduğu kal'a-i mezkûrede ve civârında zâviye-dâr olan meşâyihân ve cümle fukarâ ve sâir ahâlî hoşnûd ve râzlyân olduklarına binâen ve fevt olan baba hâl-i hayâtında iken vasiyyet eylediği vech üzere aşçıbaşı Mustafa Dede zâviye-dâr nasb olunması cümlesi niyâz ve istirhâm-1 hâl etmeleriyle merâhimi âlîlerinden mercûdur ki Boğaz gümrüğü mukataası malından yevmî on iki akçe vazîfe ile yedinde olan berât-1 âlî-şân mûcibince tarîk-i Bektâş̧iyândan aşçıaşı Mustafa Dede ol-vechile müstahakk olduğuna binâen zâviye-i mezkûra sâlifü'lbeyân on iki akçe vazîfe ile zâviye-dâr olunması bir kit'a berât-1 âlî-şân yedine i'tâ' buyrulması bâbında emr ü fermân efendim sultanım hazretlerinindir. 3 Zi-l-ka'de 1215 [18 Mart 1801], (BOA. C. EV. 607-30614).

\section{Bende el-Hacc Osman ... Muhâfiz-1 Boğaz \\ Bende es-Seyyid Mustafa diz-dâr-1 Kilidü'l-bahr}

Yukarıdaki belgede de görüleceği üzere Kilitbahir Kalesi ${ }^{15}$ yakınındaki tekkeden "e'izze-i kirâmdan Saka Baba nâm azîzin zâviyesi" olarak bahsedilmesi şüpheye yer bırakmayacak şekilde tekke isminin, veli bir kişi olduğu vurgulanan Saka Baba'dan geldiğini ifade etmektedir. Saka Baba isimli velinin ad,, tarihi yarımadanın en uç noktasında yer alan Tekke koyunda ${ }^{16}$ bulunan mezar taşlarındaki ifadelerde de karşımıza çıkmaktadır. Bir tablo halinde bu mezar taşlarındaki ifadeleri verecek olursak:

\begin{tabular}{|c|c|}
\hline \multicolumn{2}{|c|}{ Tekke Koyu'nda Yer Alan Mezar Taşlarındaki İfadeler } \\
\hline Hû & Hû \\
Merhûm ve mağfûrun-leh & Saka Meşk Baba'nın \\
Pôst-nişîni Saka Meşk & Gülü merhûm Dervîş \\
Dervîş Mustafa Baba & Hasan rûhîçün el-Fâtiha \\
Rûhuna el-Fâtiha & Sene 1229 \\
Sene 1232 & [Miladi: 1813-4] \\
[Miladi: 1816-7] & Hâsıl-1 ömrüm ciğerim pâresi \\
Hû & Gitdi elden kaldı dilde yâresi \\
Saka Meşk Baba'nın & Kil şefầat nev-civânım kuluna \\
Gülü merhûm Dervîşş & Vâlideynin yoktur gayrı çâresi \\
Ahmed rûhîçün el-Fâtiha & Ayvaz-zâde merhûm Muhammed \\
Sene 1221 & (alt kısmı kırık) \\
[Miladi: 1806-7] & \\
\hline
\end{tabular}

Dervîş Mustafa Baba'nın mezar taşını incelediğimizde Saka Baba Dergâhı pôst-nişînlerinden olduğu görülmektedir. Biraz önce zâviye-dâr tayini ile ilgili verdiğimiz belgeye göre 1801 senesinde dergâhın başına Mustafa isminde birisinin atandığı görülmektedir. Bu durumda 1801 tarihinde dergâhın başına geçen Mustafa ile Tekke Koyu'nda medfûn bulunan ve 1816-7 senesinde vefat ettiği anlaşılan ve

\footnotetext{
${ }^{15}$ Fatih Sultan Mehmet Han, İstanbul'un fethi sonrasında şehrin güvenliğini sağlamak adına Çanakkale Boğazı'nın en dar noktasına 1462-3 yıllarında iki kale inşa ettirir. Bunlardan Rumeli yakasındakine Kilitbahir, Anadolu yakasındaki Kale-i Sultaniye (günümüz Çimenlik) kalesi denir.

${ }^{16}$ Bu koy, 1915 senesinin 25 Nisan'ında Gelibolu kıyılarına asker çıkarın İngilizlerin ana çıkarma noktalarından biridir. Dolayısı ile kanlı vuruşmalara sahne olmuş bir bölgedir. Koyun ismi "Tekke" olmasına rağmen bölgede dört mezar taşından başka bir şey bulunmamaktadır. Kilitbahir Köyüne mesafesi ise yaklaşık 27 km'dir.
} 
dergâhın postnişini olduğu görülen Mustafa'nın aynı kişiler olabileceği uzak bir ihtimal değildir. Ayrıca mezar taşlarında yer alan ifadeler, bu koyda medfûn bulunan kişilerin de Saka Baba Dergâhı'na bağlı olduğunu göstermektedir.

$\mathrm{Bu}$ arada sorulması gereken diğer soru ise tekkenin hangi tarikata bağlı olduğudur. 1801 tarihli belgeye tekrar dönecek olursak, belgede yer alan "tarîk-i Bektâş̧iyândan Kabataşlı Muhammed Baba" ifadesi dergâhın Bektaşi tekkesi olduğuna işaret etmektedir. Öte yandan hem Dergâhın haziresinde hem de Tekke koyundaki mezar taşlarının başlıkları incelendiğinde birçoğunda 12 terkli Hüseynî tâcı olduğu görülmektedir. Dolayısı ile belgeler, mezar taşlarındaki ifadeler ve mezar taşlarının başlıklar ${ }^{17}$ Saka Baba Dergâhı'nın bir Bektaşi tekkesi olduğuna şüphe bırakmamaktadır.

Belge tarihine de dikkat edilecek olursa Bektaşiliğin yasaklandığı 1826 tarihinden öncesine ait olduğu görülmektedir. Bu durum biraz önce tafsilatıyla değinildiği gibi tekkenin, ilk halinde bir Bektaşi tekkesi olduğuna işaret etmektedir.

Tekrardan tekke isminin "Saka Baba" olduğuna dair kanıt olacak ifadelere dönecek olursak, bu gerçeğin tekke haziresinde medfûn bulunan Muhammed Arif Dede'nin mezar taşında da yazılı olduğu görülecektir. Muhammed Arif Dede'nin mezar taşını incelediğimizde karşımıza şu ifadeler çıkmaktadır:

Yâ Hû
"Küllü nefsin zâ'ikatü'l-mevt"
"Summe ileynâ turceûn"
Saka Baba Dergâh-1 Şerîfinde
Pôst-nişîni iken irtihâl-i dâr-1 bekâ iden
Merhûm es-Seyyid
Muhammed Arif Dede
Rûhị̂ün Fâtiha
Fî 18 Şevvâl sene 1266
[Miladi: 27 Ağustos 1850]

Muhammed Arif Dede'nin mezar taşındaki ifadelerde görüleceği üzere tekkenin ismi "Saka Baba Dergâhı"dır ve kendisi bu dergâhın pôst-nişînlerinden biridir. Kendisinin vefatı üzerine ise Şeyh Salim isminde birinin görevlendirildiği arşiv kayıtlarında mevcuttur.

\section{Taraf-1 Eşref-i Hazret-i Müsteşârîden Evkâf-1 Hümâyun Nâzırına}

Kilidü'l-bahr'da kâin Tarîkat-i Aliyye-i Kâdiryiye hân-kahı pôst-nişîni Arif Efendi'nin bilâ-veled vefâtına mebnî cihet-i meşihât Şeyh Salim Efendi'ye tevcîhi hakkında Gelibolu Meclisi'nden gelen mazbata ile i'lâm ve evrâk-1 sâire manzûr-1 saâdetleri olmak üzere leffen irsâl kılınmış olmakla emr ü irâde hazret-i men leh-ül emrindir. 25 Safer [12]67 [30 Aralık 1850], (BOA. A. MKT. NZD. 22-68).

bâ-işâret-i hazret-i müsteşârî

${ }^{17}$ Bu konuda sanat tarihçisi Emel Başaran'dan uzman görüşü alınmıştır. 
Belgede dikkatleri çeken diğer bir önemli husus ise tekkeden Kadiriye tekkesi olarak bahsetmesidir. 30 Aralık 1850 tarihli bu belgeye göre, 1826'da Bektaşiliğin yasaklanmasından sonra tekkenin kapanmayıp Kadiriye tarikatına geçtiği değerlendirilmektedir. Bu durumda "Kadir Baba" isminin tarikatın isminden gelmiş olması diğer bir olasılık olarak karşımıza çıkmaktadır. Bu arada Şeyh Salim'in zâviye-dâr olarak atanmasıyla ilgili 1851 tarihli diğer bir belgede, Bektaşiliğin yasaklandığı tarihten sonrasına ait olmasına rağmen tekke isminin değişmediği ve yine kayıtlara Saka Baba Dergâhı olarak geçtiği görülmektedir.

\section{Evkâf-1 Hümâyun Nâzırına}

Kilidü'l-bahr Kal'ası kurbinde vâki' olub mahlûl olan Saka Baba zâviye-dârllğı hakkında gönderilen tahrîrât-1 senâ-verîye cevâben Gelibolu Meclisi’nden vârid olub, üzerine kuyûd-i lâzımesi ihrâc olunan i'lâm ile merbût mazbatalar manzûr-1 vâlâları buyrulmak üzere leffen gönderilmiş olduğu beyânıyla tezkere. 17 Cemâzi-yel-evvel 1267 [20 Mart 1851], (BOA. A. MKT. NZD. 30-15).

\section{bâ-işâret-i aliyye-i hazret-i müsteşârî}

Özetle Saka Baba Dergâhı Kadiriye Tarikatı idaresine geçmiş olsa bile isminin değişmediği açıktır.

1889-90 tarihinde vefat ettiği anlaşılan Hüseyin Haydar Baba'nın mezar taşındaki ifadeler incelendiğinde ise tekkenin başına tekrardan Bektaşî tarikatına mensup birisinin geçtiği görülmektedir. Ancak bu değişimin ne zaman gerçekleştiğine dair maalesef bir kayıt bulunmamaktadır.

Yâ Hû
Bu makâmda pôst-nişîn hem bâni-i sâni idi
Her mihmâna eyler idi izzet ile hidmeti
Zümre-i Bektâşiyândan Hüseyin Haydar Baba
Kalbi[ni] dinlendirüb çaldı nefîr-i rihleti
Şâfi'î Âl-i abâ olsun bi-hakk-1 Kerbelâ
Sâfi-i kevser suna ukbâda câm-1 şerbeti
Sidkile târîh-i fevtin yazdı bir ehl-i niyâz
Lutf-i Hakk imdâd-1 pîr-ân kıldı menzil cenneti
Kilidü'l-bahrli Hâcı Muhammed Baba-zâde
Hüseyin Baba'nın rûhîçûn el-Fâtiha
Sene 1307
[Miladi: 1889-90]
(Kitabe metni
yazılmıştır)
(Fâ’ilâtün / Fâ'ilâtün / Fâ'ilâtu / Fâ'ilün vezniyle
(4. satırdaki [ni] eki vezin gereği tarafimızca
eklenmiştir. Ancak ikinci 2. Satırda zihâf denilen
kusur mevcuttur.)
(Mezar taş1 “12 terkli Hüseynî tac” denilen başlığa
sahiptir.)


Sultan II. Mahmut döneminden sonra 1826 yılında faaliyetlerine son verilen Bektaşî tekkelerinin tekrar açıldığı bilinmektedir (Maden, 2012, s. 73). Bu durumda, belgeler ve mezar taşlarındaki ifadelerden elde edilen bilgilere göre tekke, bir ara Kadiriye Tarikatı'nın idaresine geçse de bir müddet sonra yeniden ilk haline yani Bektaşî tekkesine dönüştüğü anlaşılmaktadır. 1906-7 senesinde vefat ettiği anlaşılan Mahmut Efendi'nin mezar taşındaki ifadelerde bu görüşü destekler niteliktedir.

Sene 1324 / [Miladi: 1906-7]
Yâ Hû
Fenâdan bekaya eyledi rıhlet
İde kabrini Hak ravza-i Cennet
Tarîkat-1 Aliyye-i Bektâşiyeden
Saka Baba Dergâhı pôst-nişîni
Hâcı Muhammed Efendi'nin mahdûmu
Mahmud Efendi'nin
Rûhuna Fâtiha
(Kitabe metninin ilk iki satırı
Mefâ'îlün / Mefâ'îlün /Fe'ûlün
Vezni ile yazılmışır)

Sonuç olarak günümüzde Kadir Baba Tekkesi olarak bilinen tekkenin gerçek ismi yukarıda sunulan deliller ışığında "Saka Baba Dergâhı”dır. Bu görüşün kabul edildiği başka çalışmalarda mevcuttur. Ayşe Değerli ve Yusuf Küçükdağ, çalışmalarında vermiş oldukları listede Kilitbahir'deki tekkeden "Saka Baba Zaviyesi" olarak bahsetmektedirler (Değerli ve Küçükdağ, 2017, s. 105). Bir Bektaşî tekkesi olan Saka Baba Dergâhı, 1826 yılında Bektaşîliğin yasaklanması ile bir dönem Kadiriye Tarikatı idaresine geçse de bir zaman sonra tekrardan ilk hüviyetine dönmüştür. Tekke isminin bu tespitler 1şığında kendi ismiyle anılması aynı zamanda literatürde yer alan diğer "Kadir Baba" isimli tekkelerle ${ }^{18}$ karıştırılması olasılığını da önleyerek bundan sonraki çalışmalara da 1şık tutacağına inanılmaktadır. Tekkede mevcut koşullarda ayakta kalan tek yapı ise türbesidir.

\section{SAKA BABA DERGÂHI HAZIRESİ}

Tekkenin haziresi bugün kaçak kazılar ve zamanın tahribatıyla kötü durumdadır. Mezar taşlarının birçoğu yerinden çıkmış, bir kısmı da yerinden çıkmak üzere yatık durumda ve bazıları kırılarak etrafa dağılmış vaziyettedir. 2011 yılında Eceabat Kaymakamlığı için yapılan yüzey araştırmasında 14 mezar taşı tespit edilmiş ancak yukarıda da ifade edildiği gibi 2017 yılında Çanakkale Savaşları Gelibolu Tarihi Alan Başkanlığı adına gerçekleştirilen yüzey araştırmasında bunlardan 13'ü tekrardan tespit edilmiştir. Ne yazık ki tekkeye ismini veren Saka Baba isimli veli zatın mezar taşı tespit edilememiştir. Bu sebeple çalışmada, Saka Baba'ya ait olan mezar taşının 2011 senesinde çekilmiş fotoğrafı kullanılmıştır. Çünkü artık yeniden fotoğraflanma imkanı kalmamıştır.

Mezar taşlarında yapılan incelemede hazirede medfûn şu kişilerin bilgilerine ulaşılmıştır.

\footnotetext{
${ }^{18}$ Literatürde "Kadir Baba Tekkesi” ismiyle maruf bir tekke de Selanik’te gözükmektedir. Bkz. (Kayapınar, 2010, s. 254).
} 


\begin{tabular}{|c|c|c|c|}
\hline \multicolumn{4}{|c|}{$\begin{array}{c}\text { Saka Baba Dergâhı'nda Medfûn Bulunan Kişiler } \\
\text { (Vefat Tarihlerine Göre Sıralanarak) }\end{array}$} \\
\hline \multirow{2}{*}{\multicolumn{2}{|c|}{ İsmi }} & \multicolumn{2}{|c|}{ Vefat Tarihi } \\
\hline & & Hicrî & Miladi \\
\hline 1 & Saka Baba & 1180 & $1766-7$ \\
\hline 2 & Seyyid Hamza Baba & 1211 & $1796-7$ \\
\hline 3 & Fâtımatü’z-Zehra & 1214 & $1799-1800$ \\
\hline 4 & Kasımpaşalı Mahmud Kapudan & 1222 & $1807-8$ \\
\hline 5 & Hâcı Ahmed oğlu Ali & 1228 & 1813 \\
\hline 6 & Seyyid Muhammed Arif Dede & Fî 18 Şevvâl sene 1266 & 27 Ağustos 1850 \\
\hline 7 & Seyyid el-Hacc İbrahim & 1278 & $1861-2$ \\
\hline 8 & Hâcı Muhammed Efendi & $\begin{array}{c}\text { Fî } 11 \text { Şevvâl Sene } \\
1283\end{array}$ & 16 Şubat 1867 \\
\hline 9 & Hâcı Edhem & 1285 & $1868-9$ \\
\hline 10 & Bey Hüseyin & 1299 & $1881-2$ \\
\hline 11 & Hüseyin Baba & 1307 & $1889-90$ \\
\hline 12 & $\begin{array}{l}\text { İsimsiz ama başlığından bir kadına ait } \\
\text { olduğu anlaşılan bir mezar taşı }\end{array}$ & 1312 & $1894-5$ \\
\hline 13 & Mahmud Efendi & 1324 & $1906-7$ \\
\hline 14 & $\begin{array}{l}\text { Kırık olduğu için ismi okunamayan bir } \\
\text { mezar taşı }\end{array}$ & Kırık & Kırık \\
\hline
\end{tabular}

Yukarıda da değinildiği gibi bunlardan dördünde "Saka Baba Dergâhı" ibaresi tespit edilmiş ve bu tespit sonucunda bu çalışma gerçekleştirilmiştir. Mezar taşlarından 12 kişinin kimliği açık bir şekilde tespit edilirken bir tanesinde isim belirtilmemiştir. Ancak isim belirtilmeyen mezar taşının başlığındaki süslemeden, bir kadın mezarı olduğu anlaşılmaktadır. Bir tane de kırık olduğu ve alt kısmına da tesadüf edilemediği için kimliği tespit edilemeyen bir mezar taşı daha bulunmaktadır.

Çalışma içerisinde zikredilen 4 mezar taşının haricinde tekke haziresinde mevcut diğer mezar taşlarının günümüz Türkçesi ile karşılığı ise aşağıdaki tablodaki gibidir. 


\section{Saka Baba Dergâhı Haziresinde Mevcut Diğer Mezar Taşları}

Hû

Merhûm Seyyid

Hamza Baba

Rûhuna Fâtiha

Sene 1211

[Miladi: 1796-7]

Âh mine'l-mevt

İstihkâm Kolağalarından

Ali Rıza Efendi'nin

Kerîmesi

Fâtımatü'z-Zehra

Rûhuna Fâtiha

Fî sene 1214

[Miladi: 1799-800]
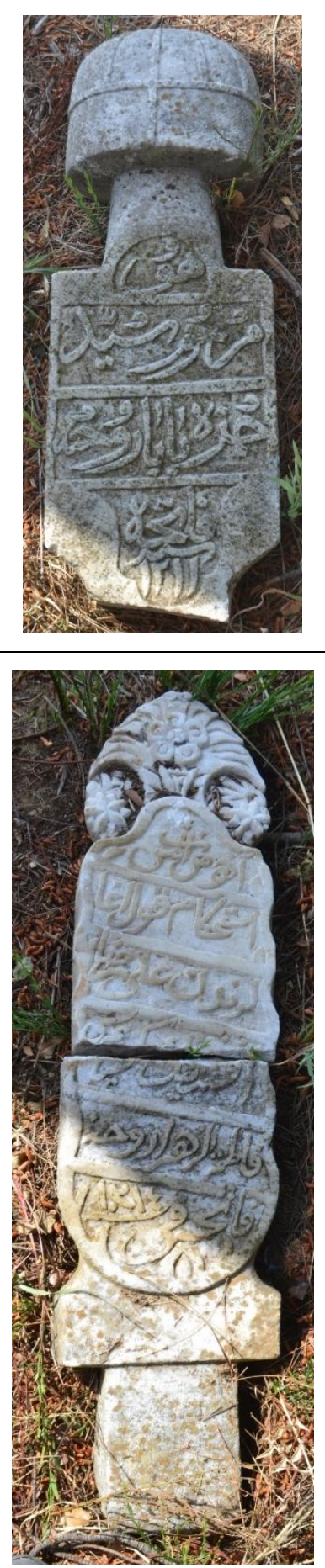


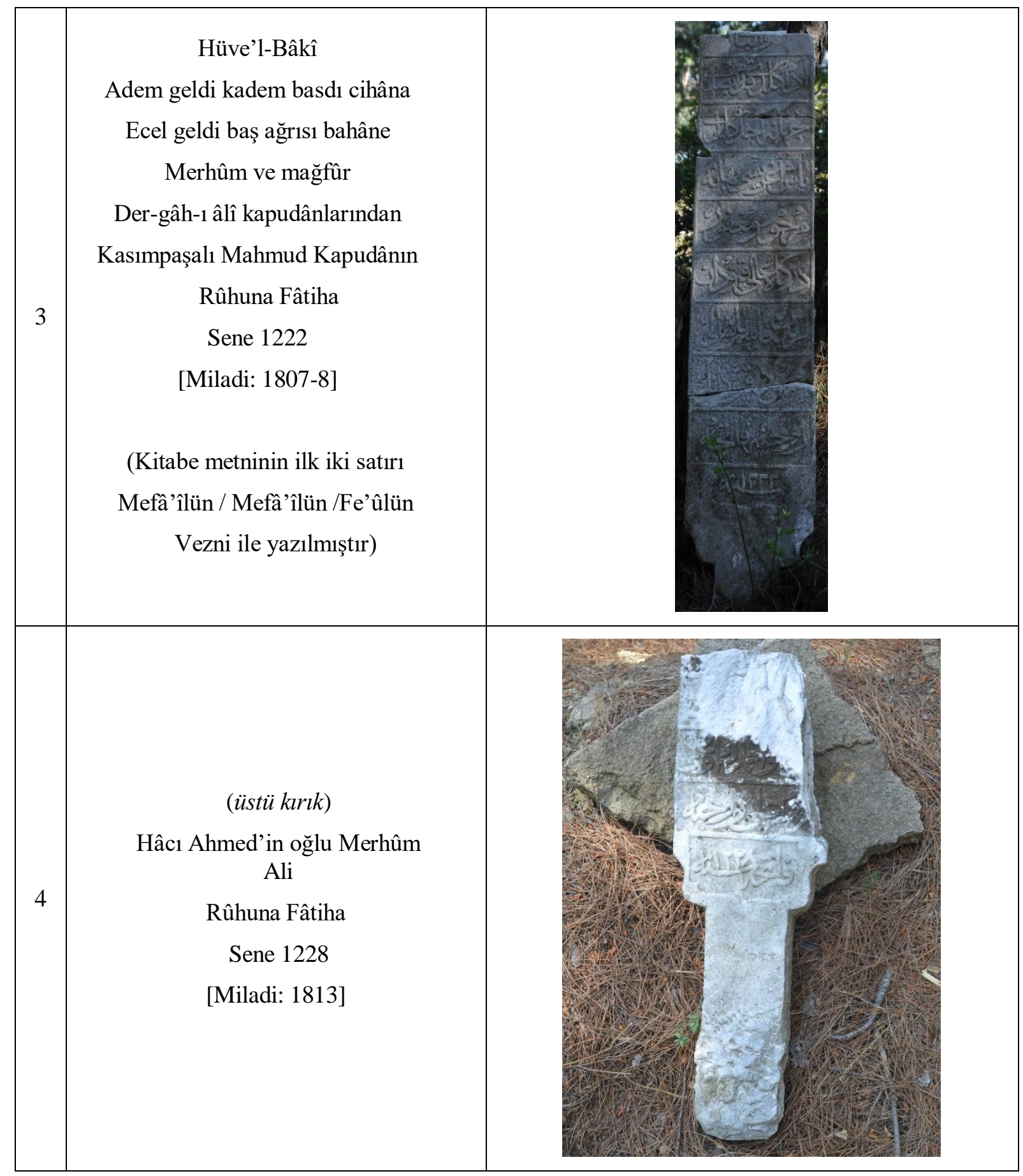




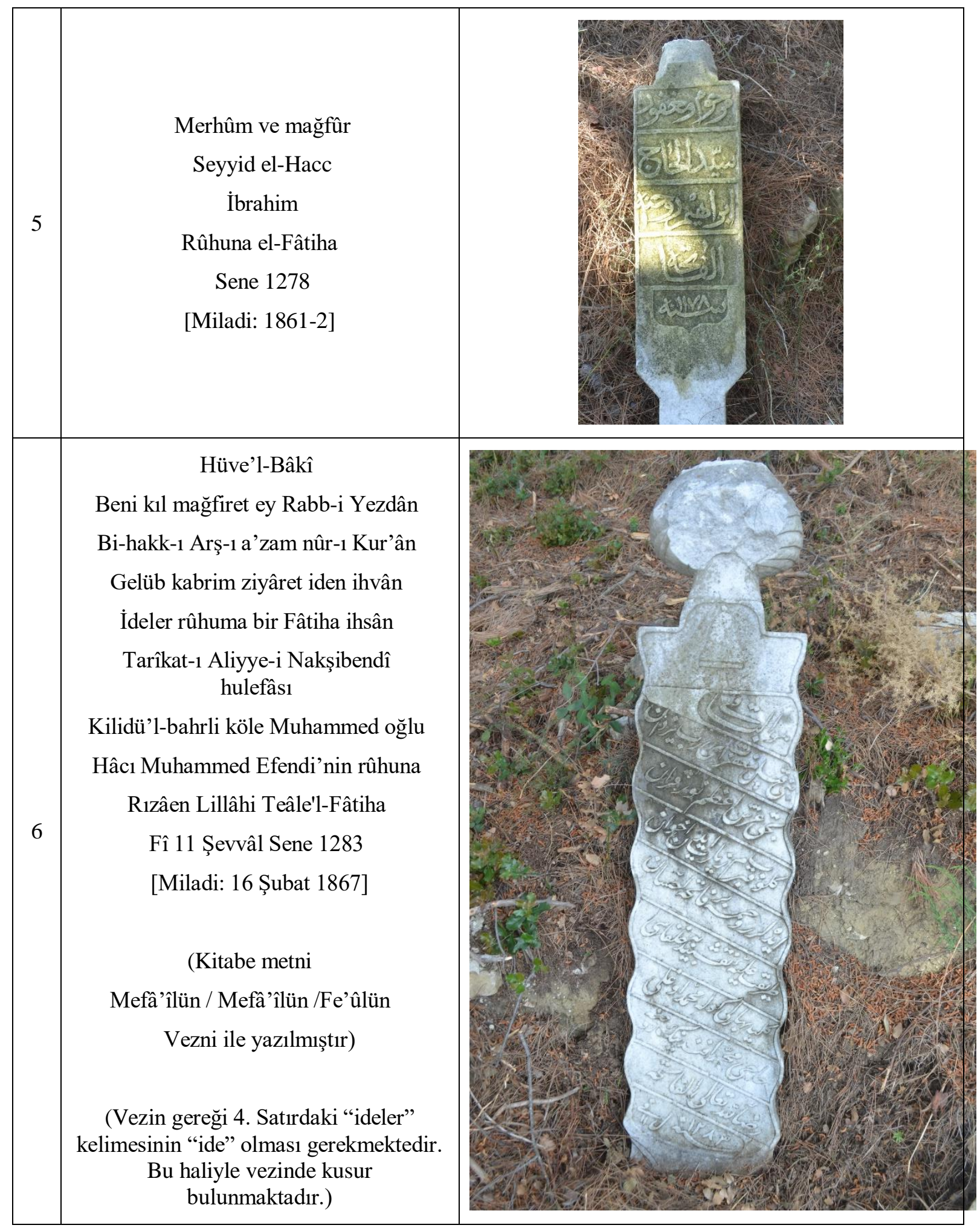




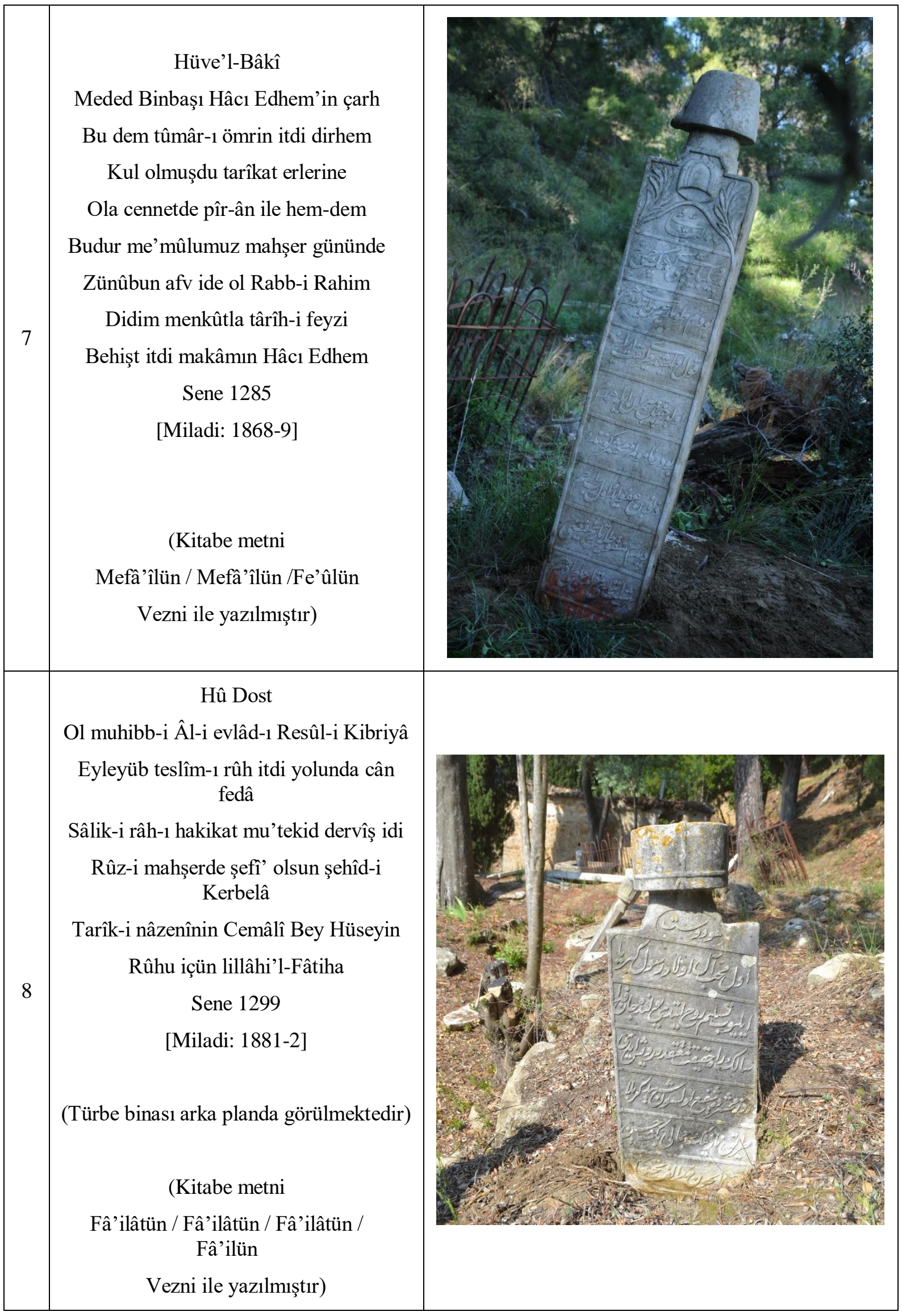




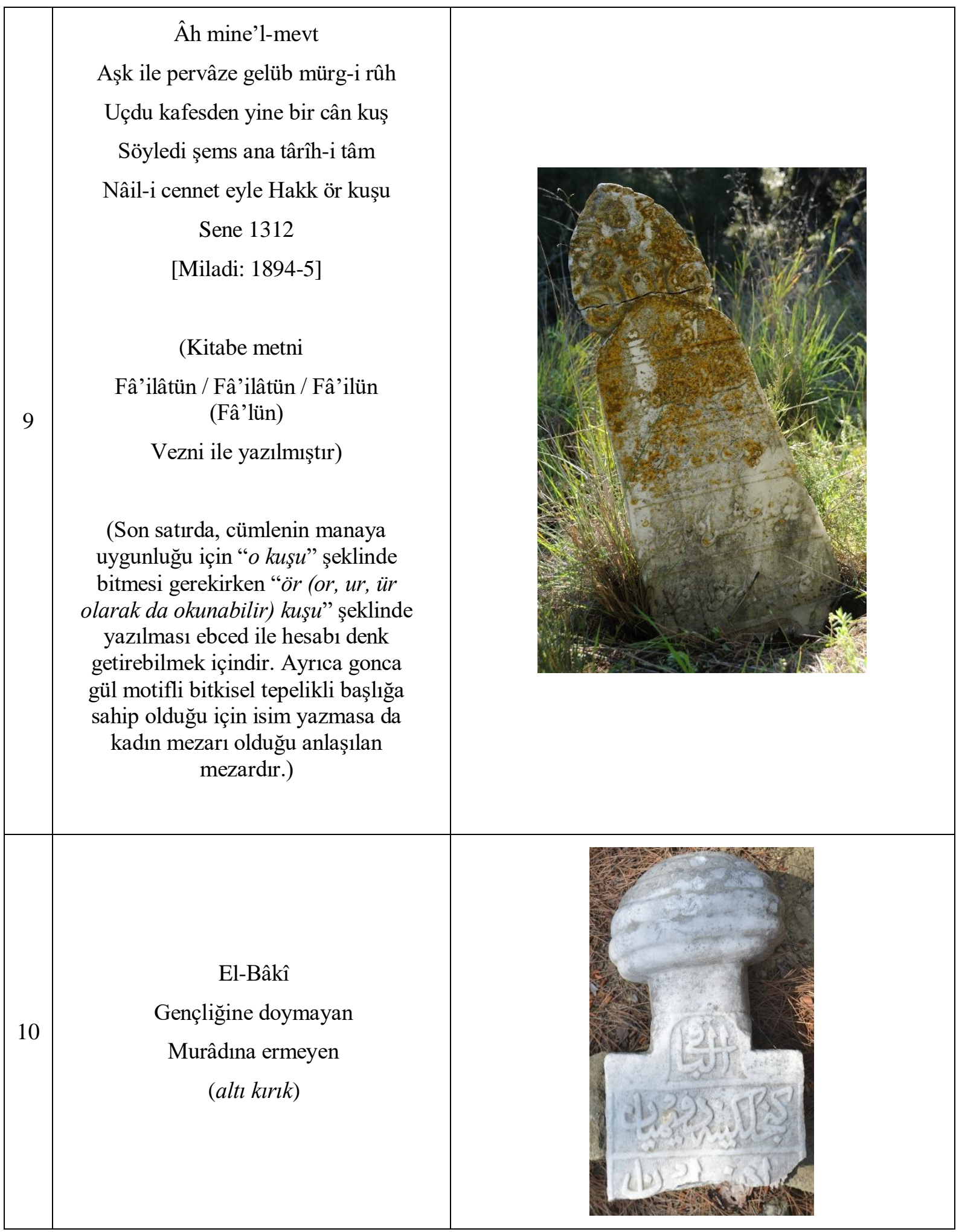

\section{KAYNAKÇA}

Afyoncu, E. (2005). Sorularla Osmanlı İmparatorluğu II. 10. Bask1, İstanbul: Yeditepe Yayınevi.

Altıer, S. (2018). Çanakkale'de Osmanlı Dönemi tasavvuf ortamının izleri: Tarikat yapıları. Çanakkale Araştırmaları Türk Yıllığı, 24, 79-132. 
Değerli, A. ve Küçükdağ, Y. (2017). Vesâik-i Bektaşiyân'da yer almayan Rumeli'deki Bektaşi yapıları (1400-1826). Alevilik Araştırmaları Dergisi, 13, 105-136.

İnalcık, H. (2017). Osmanlı ve modern Türkiye. 4. Baskı, İstanbul: Timaş Yayınları.

Kayapınar, L. (2010). Balkanlarda erken dönem Osmanlı akıncı uçbeyleri Bektaşi miydirler?. Doğumunun 800. Yılında Hacı Bektaş Veli Sempozyumu Bildiriler, Ankara: Atatürk Kültür Merkezi Yayınları, 245-268.

Kurtman, N. (1991). Çanakkale eserlerinden örnekler. Vakıf Haftası Dergisi, 8, 171-178.

Maden, F. (2012). Edirne vilayetinde Bektaşî tekke ve türbeleri. Türk Kültürü ve Hacı Bektaş Velî Araştırmaları Dergisi, 64, 55-76.

Özel, Ş. (1991). Çanakkale tesbit çalışmaları. Vakıf Haftası Dergisi, 8, 165-170.

Pekselek, M., M. (2018). Ihtiyat zabiti Münim Mustafa'nın harp hatıraları, Kanal Seferi'nden Çanakkale'ye. (haz. Ahmet Yurttakal). İstanbul: Yeditepe Yayınları.

Şimşek, S. (2007). Avrupa ile Asya arasında önemli bir geçiş noktası Gelibolu'da tarikatlar ve tekkeler. Selçuk Üniversitesi Türkiyat Araştırmaları Dergisi, 22, 251-310.

Tuncer, O., C. (1991). Anadolu kümbetleri 2 beylikler ve Osmanlı dönemi. Ankara: Sevinç Matbaası.

Yönem, A. (2015). Tarihi süreç içinde Çanakkale'de Bektaşilik. Alevilik Araştırmaları Dergisi, 9, 75-90.

\section{ARȘIV BELGELERI}

Cumhurbaşkanlı̆̆ı Osmanlı Arşivi, Cevdet Tasnifi Evkaf (BOA. C. EV.), 607-30614.

Cumhurbaşkanlı̆̆ı Osmanlı Arşivi, Sadâret Mektûbî Kalemi Nezâret ve Devâir (BOA. A. MKT. NZD.), 22-68.

Cumhurbaşkanlı̆̆ı Osmanlı Arşivi, Sadâret Mektûbî Kalemi Nezâret ve Devâir (BOA. A. MKT. NZD.), 30-15. 


\section{EKLER}

\section{EK 1}

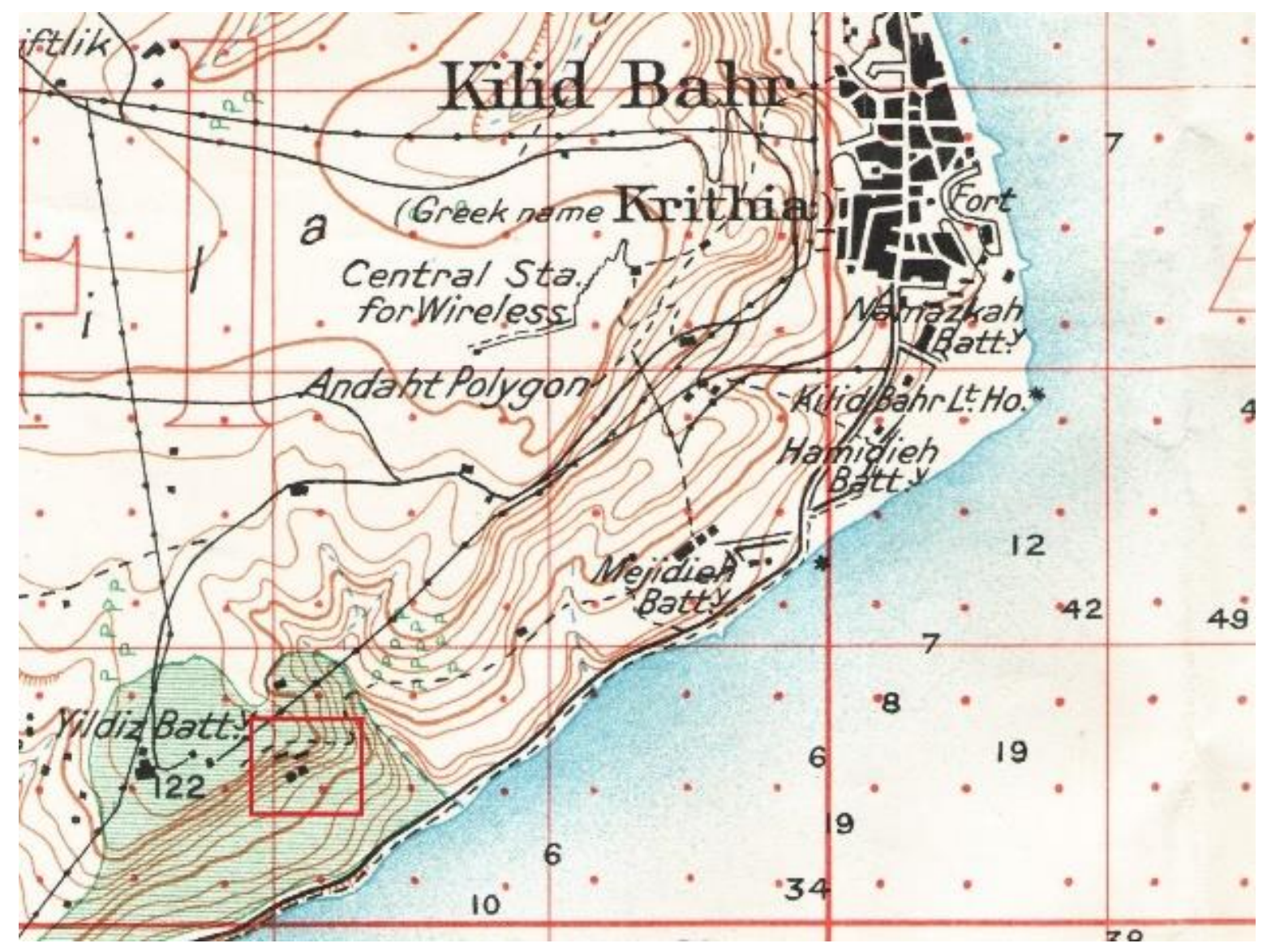

1915 yılında Çanakkale Muharebelerinde İngilizlerden ele geçirilen haritada, sol altta kırımızı işaretle çevrelenmiş alanda Yıldız Tabyası'nın alt kısmında tekke binalarını gösterir işaretler (Şaban Murat Armutak Arşivi)

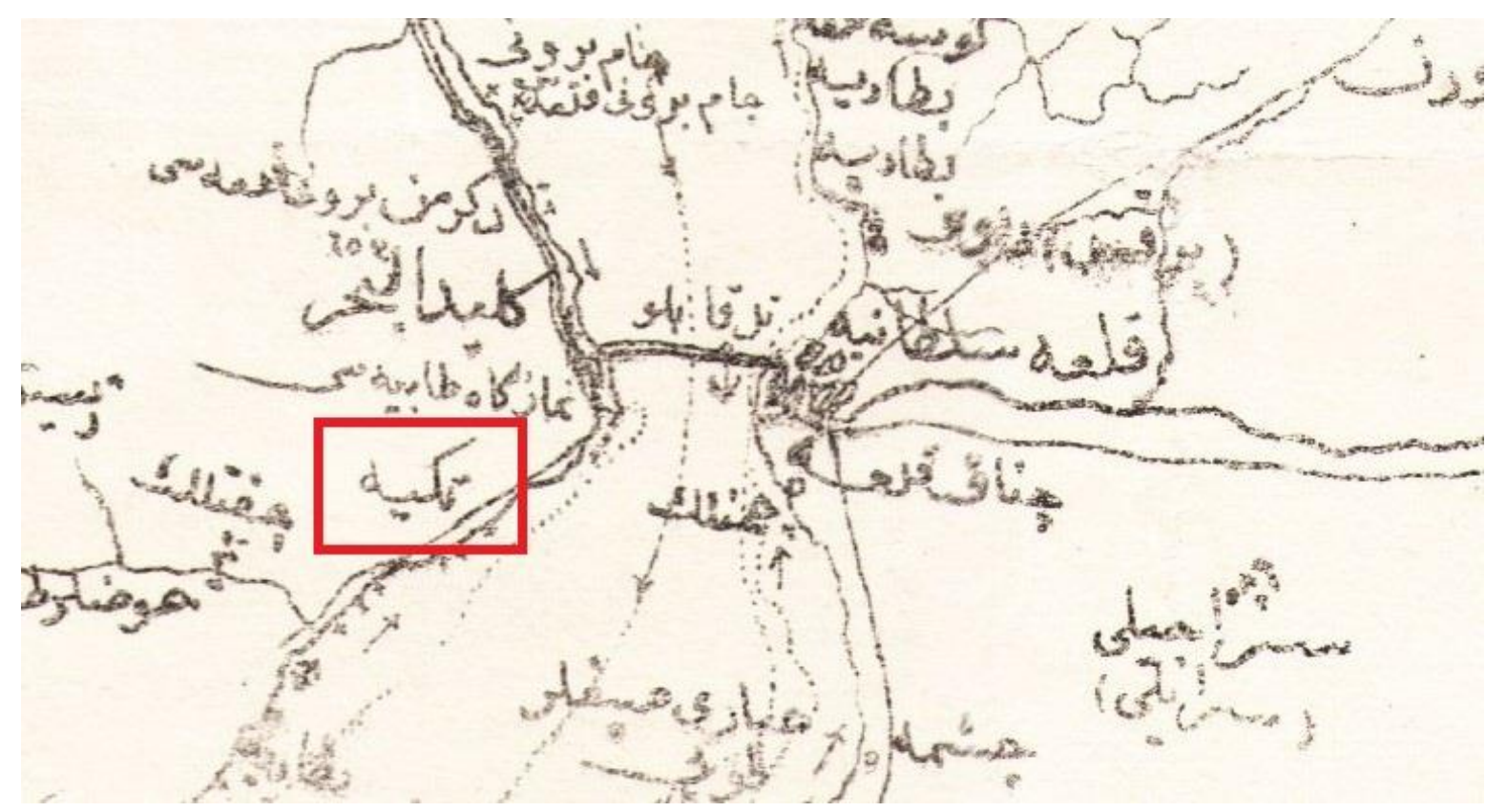

Osmanlı haritasında, işaretli alanda "Tekke" diye belirtilen Saka Baba Dergâhı (Şaban Murat Armutak Arşivi) 


\section{EK 2}

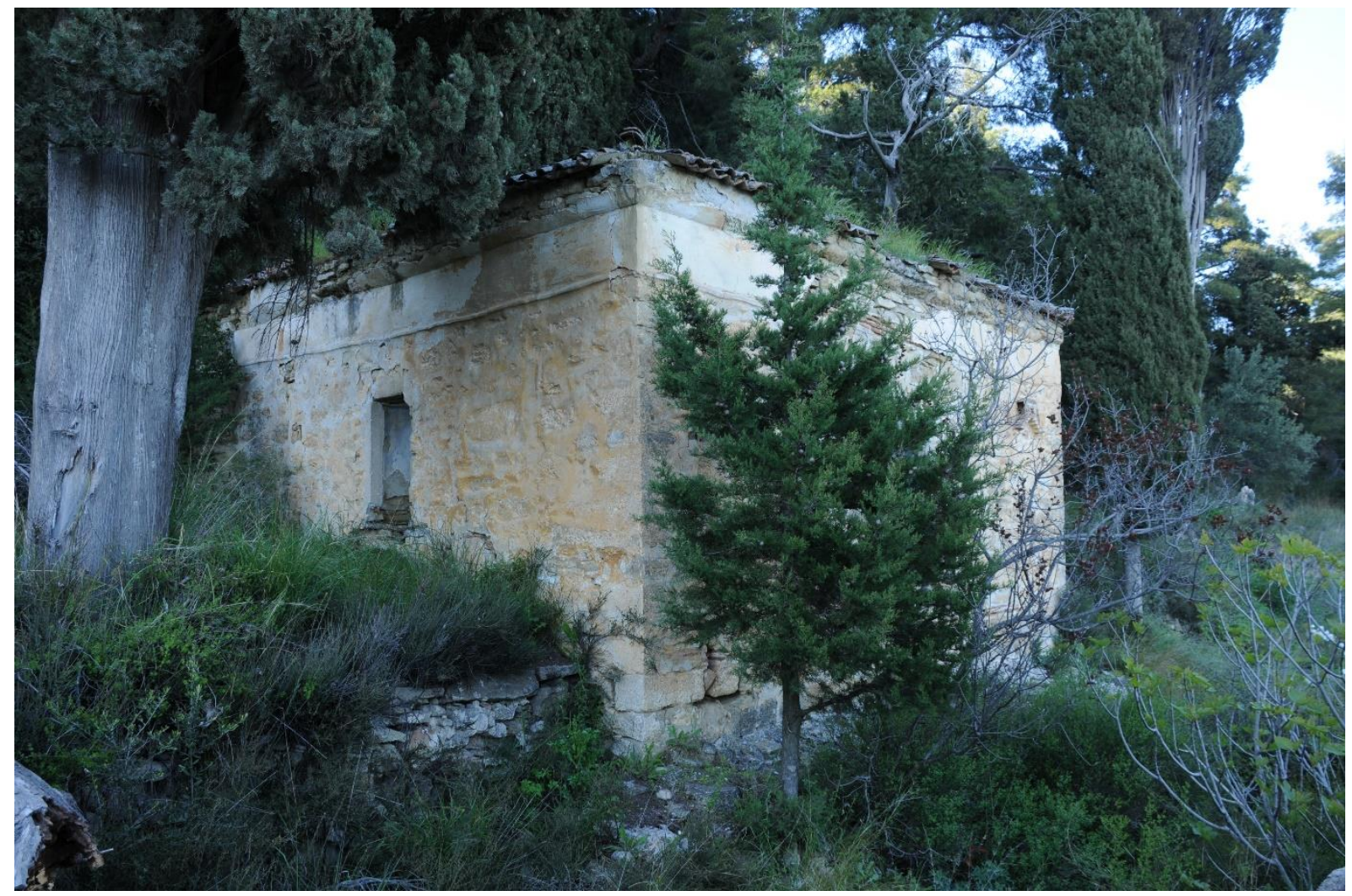

Tekkenin ayakta kalan tek yapısı olan türbe binası

\section{EK 3}

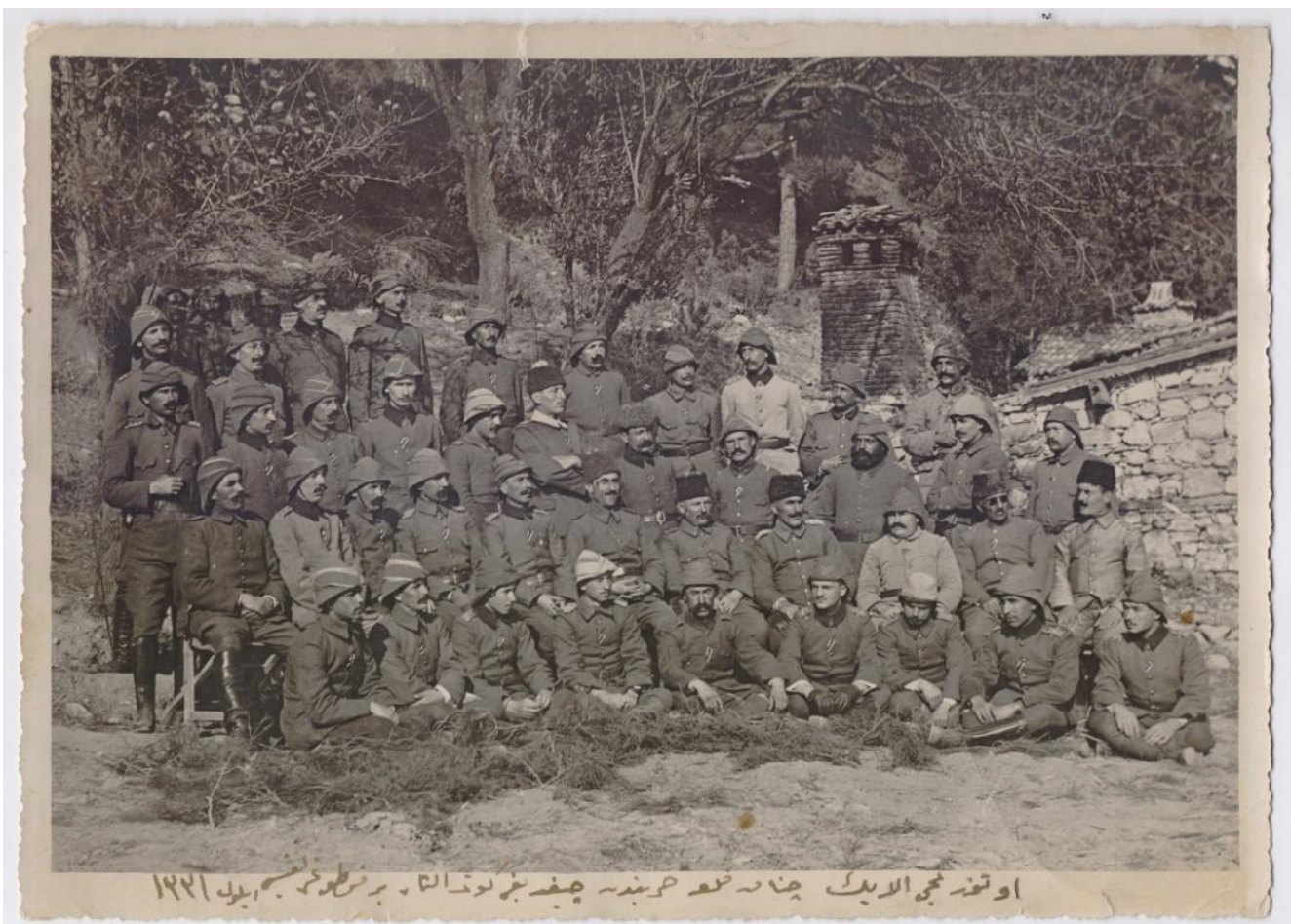

Münim Mustafa Pekselek tarafından 1915 yılında Çanakkale Muharebeleri esnasında Saka Baba Dergâhı'nda çekilmiş fotoğraf. Fotoğraf üzerinde "30. Alayın Çanakkale harbinden çıktığı gün alınan bir fotoğrafı Eylül 1331” ifadeleri yer almaktadır. (Ahmet Yurttakal Arşivi) 


\section{EK 4}

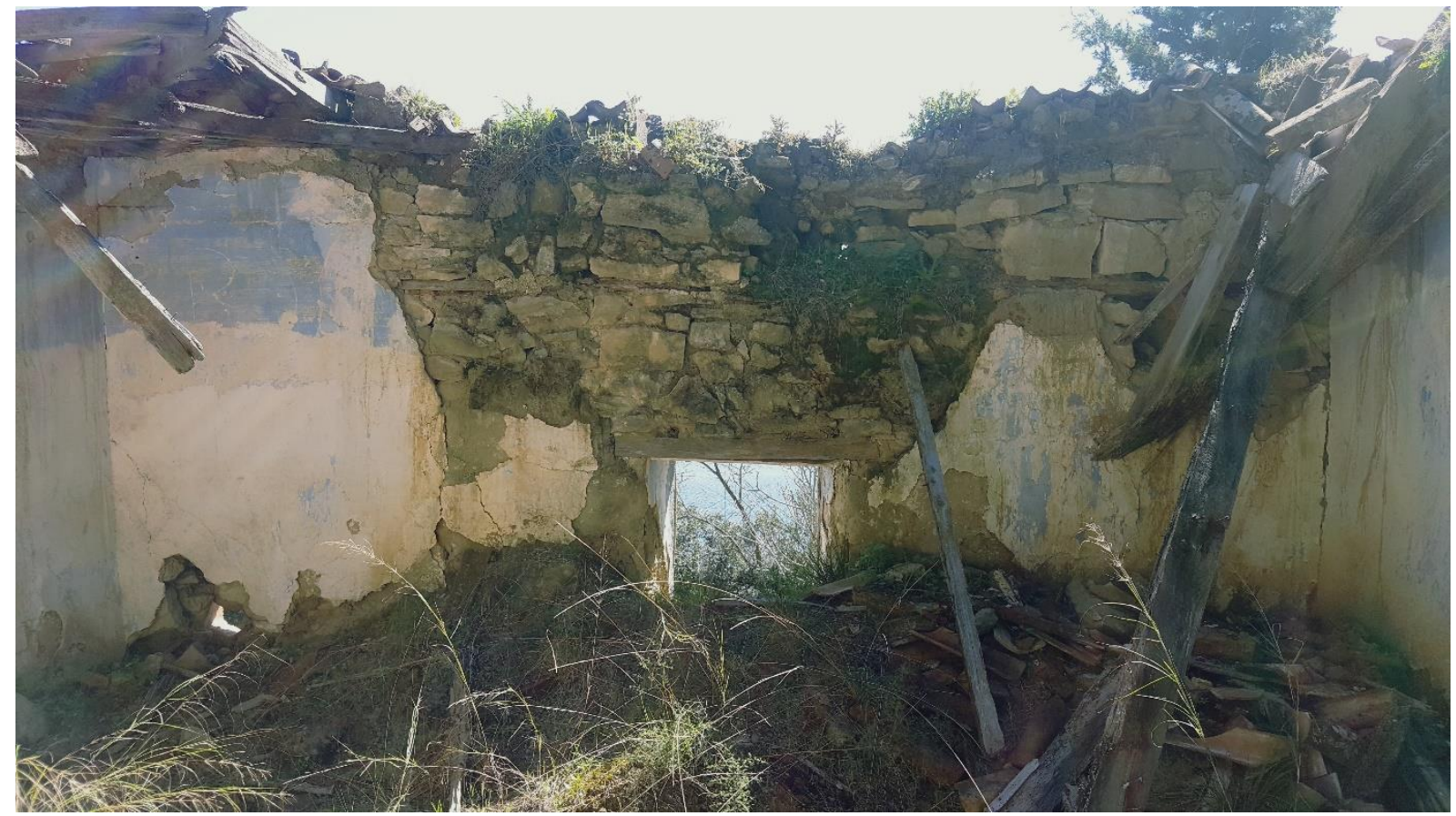

Türbe yapısının iç güney duvarı

\section{EK 5}

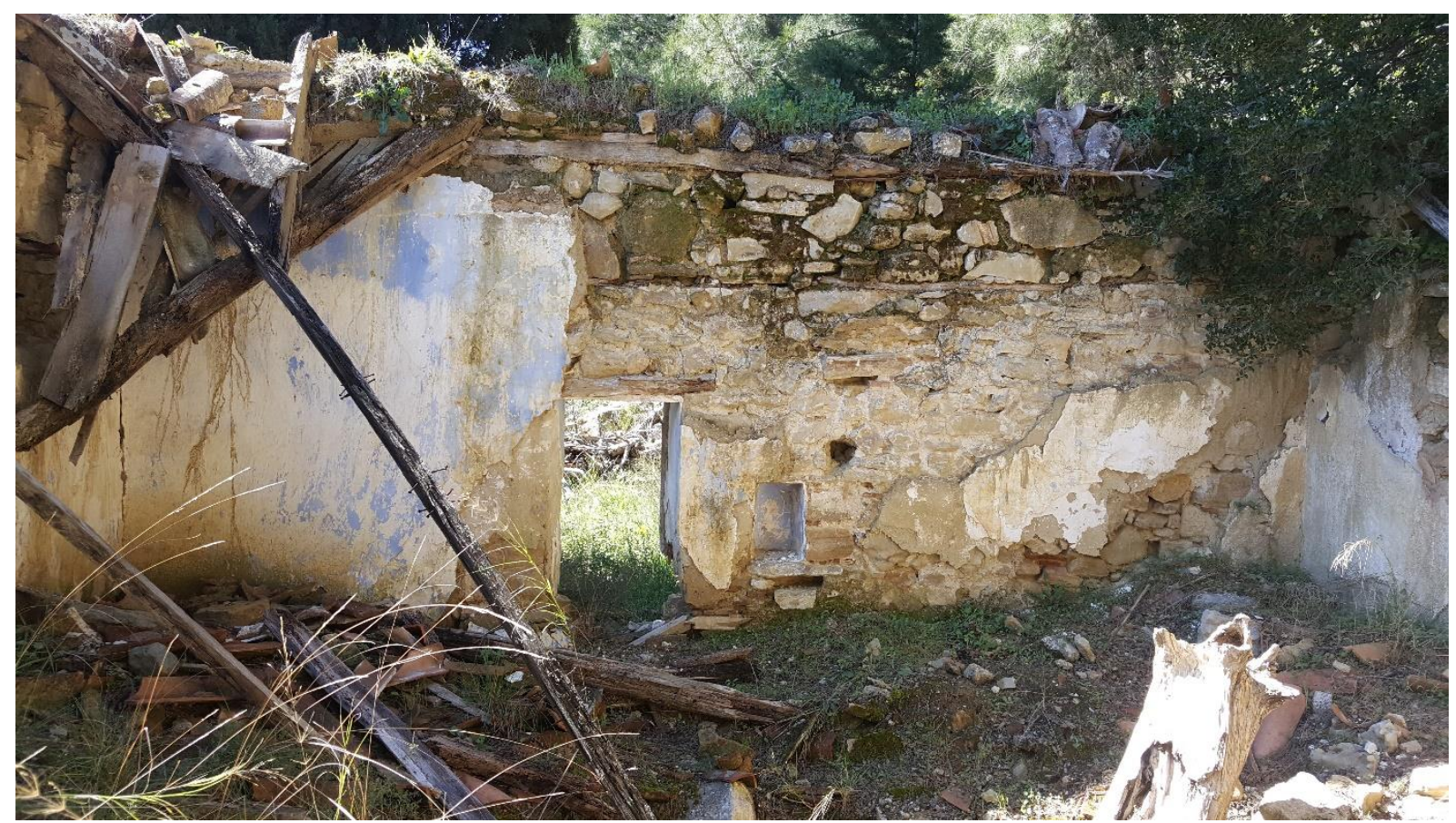

Türbe yapısının iç batı duvarı. Duvarın sağ tarafında 2011 senesinde mevcut olan süsleme, sıvaların dökülmüş olması nedeniyle artık görülmemektedir. Süsleme için bkz. EK 9. 


\section{EK 6}

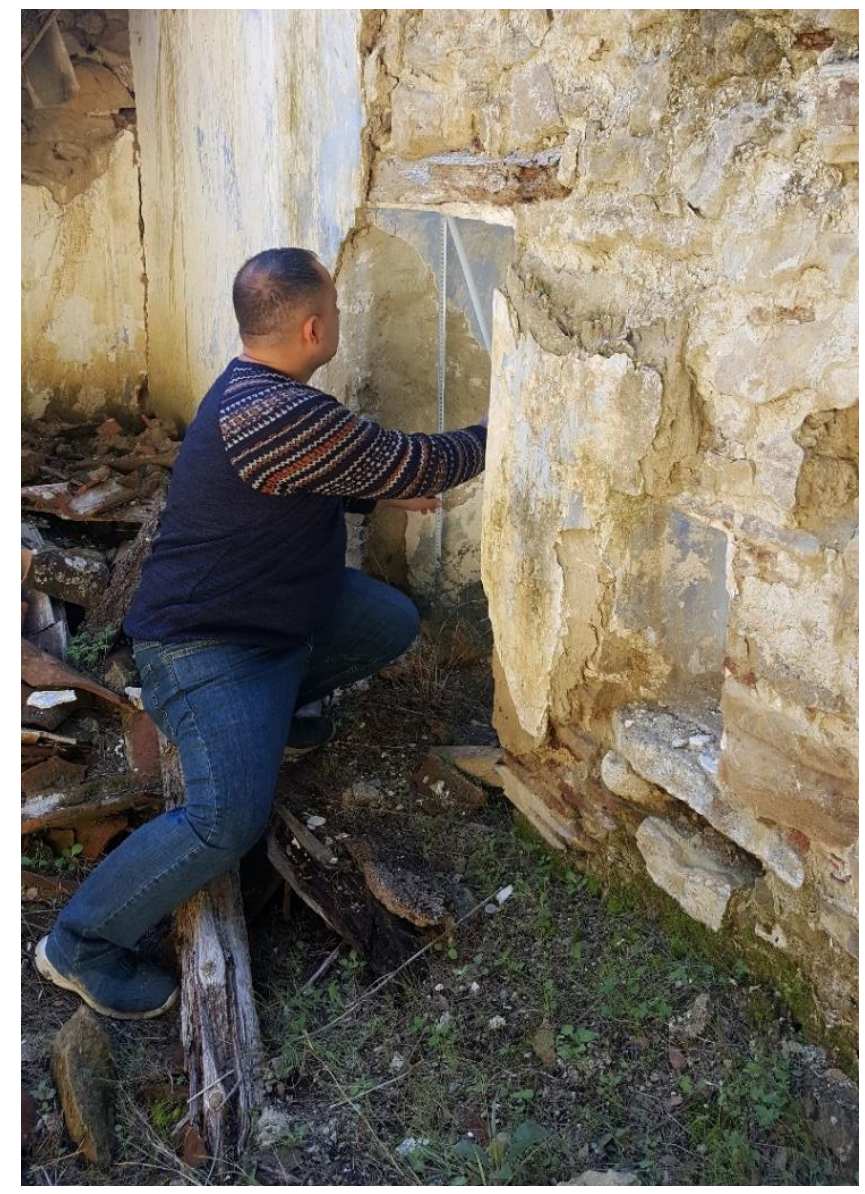

Türbe yapısının iç batı duvarında pencere ölçümü

\section{EK 7}

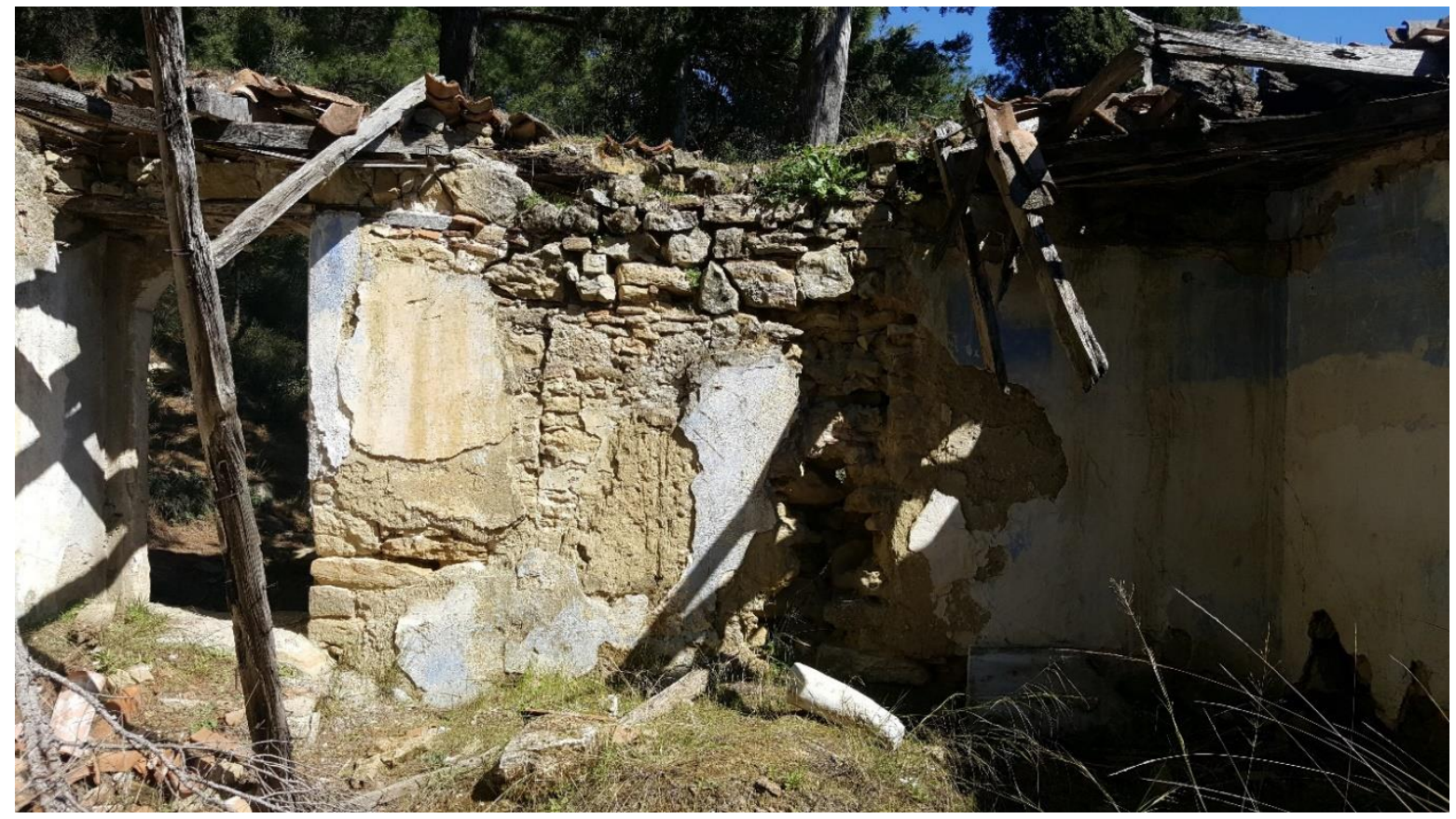

Türbe yapısının iç doğu duvarı. Bu duvarda olduğu bahsedilen dolap yapısı, tahribat nedeniyle net olarak seçilememektedir. 


\section{EK 8}

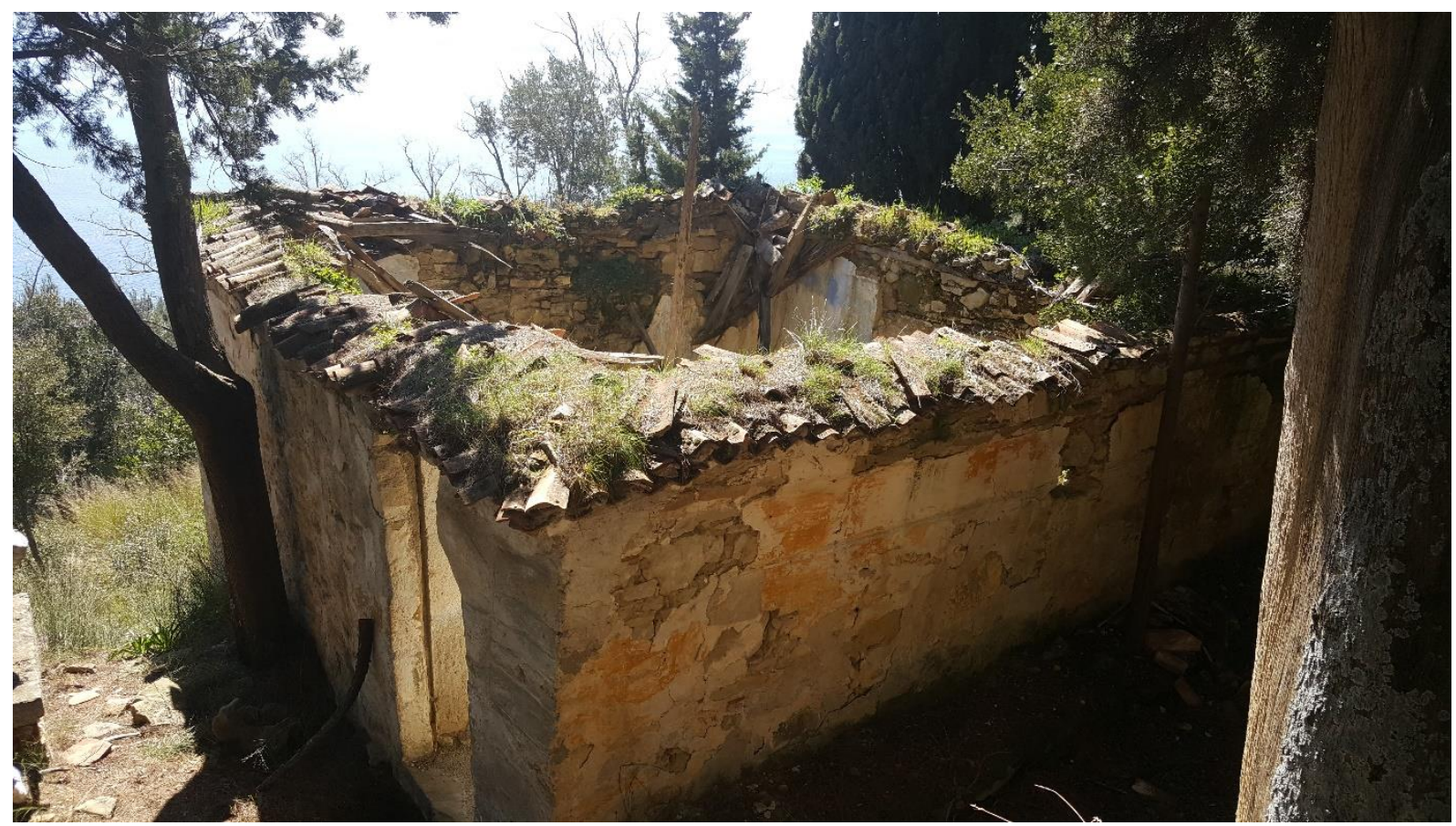

Türbe yapısının yukarıdan görünüşü ve doğu tarafından giriş kapısı ile çatısında mevcut kalan kiremitler.

Arka planda Çanakkale Boğazı manzarası.

\section{EK 9}

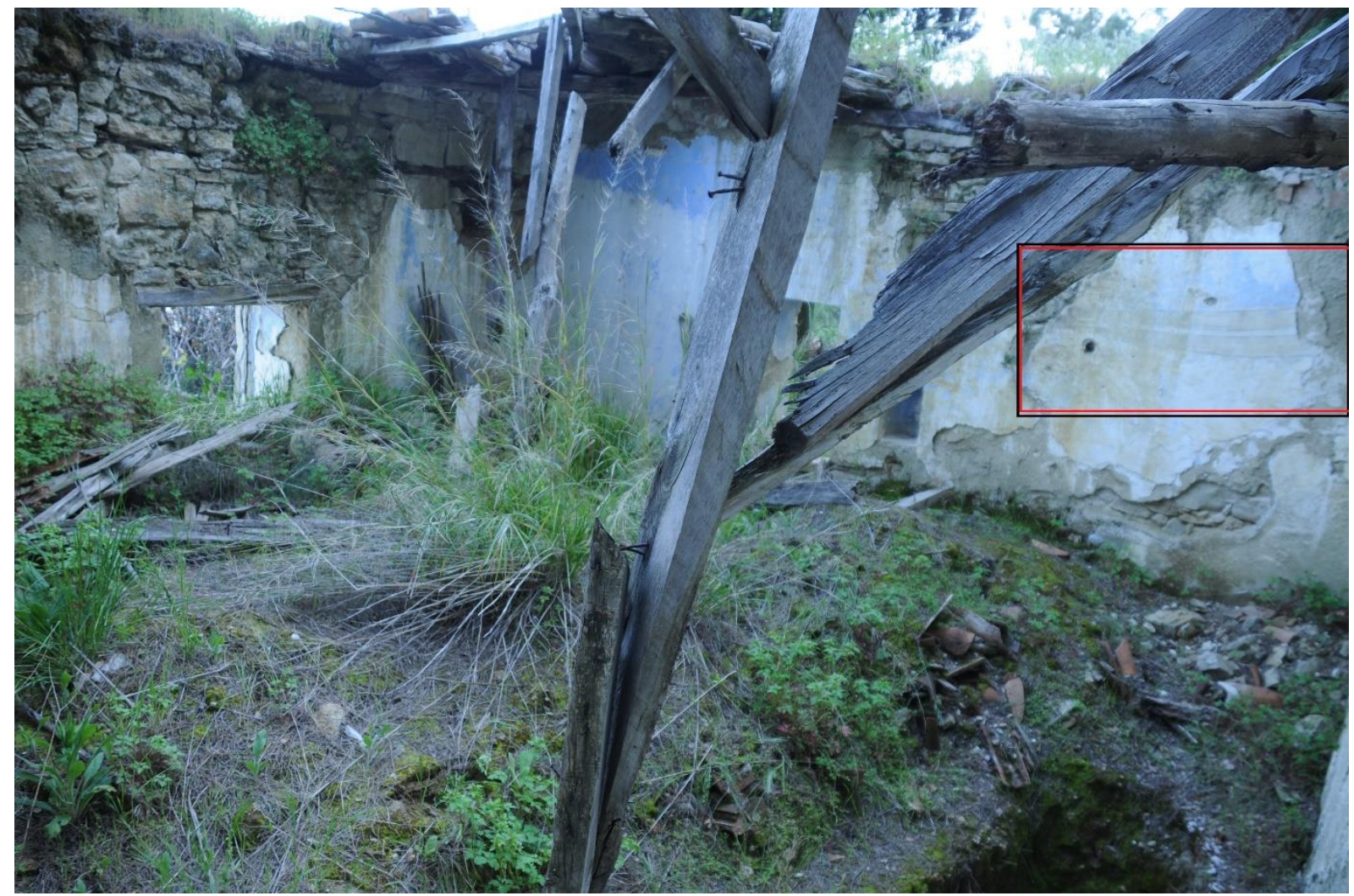

2011 yılında türbe yapısının iç batı duvarında Zülfikar'a benzettiğimiz süsleme ve giriş kapısının önünde yapılan kaçak kazının izleri. 2019'da türbe yapısının ortası kazılı durumdadır. Bu kazı esnasında çıkan toprağın bu fotoğrafta görülen eski kazı çukuruna doldurulduğu gözlemlenmiştir. 


\section{EK 10}

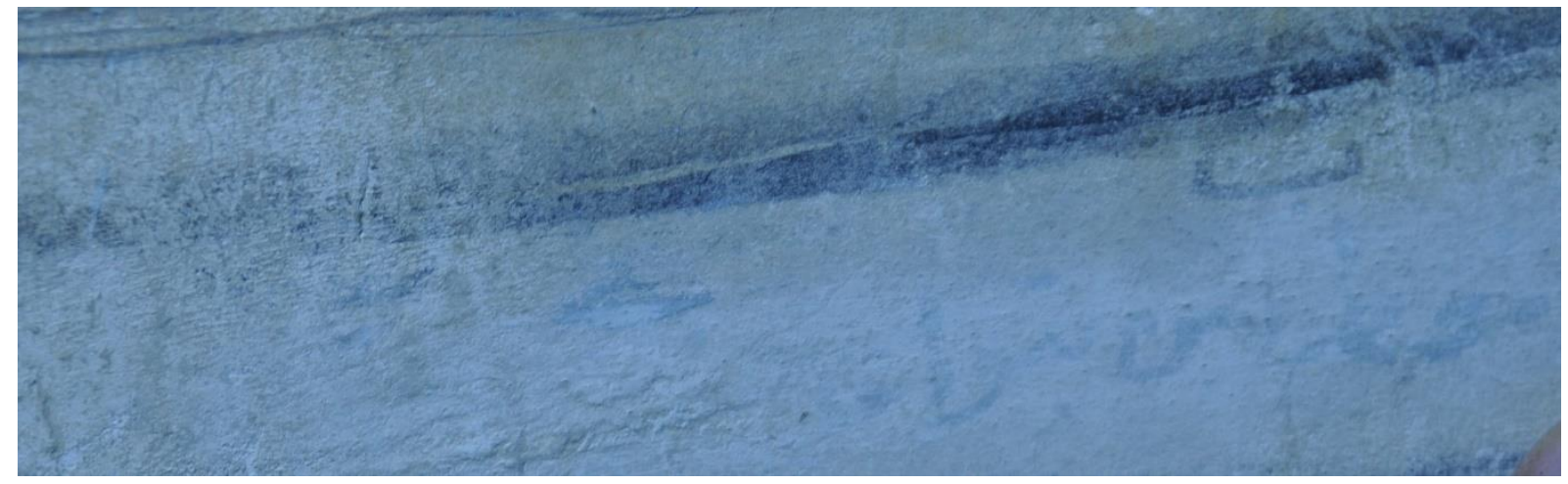

2011 yılında fotoğraflanan ancak şuan günümüzde mevcut olmayan, Zülfikar’a benzettiğimiz süsleme içinde tahribat nedeniyle okuyamadığımız yazılar

\section{EK 11}

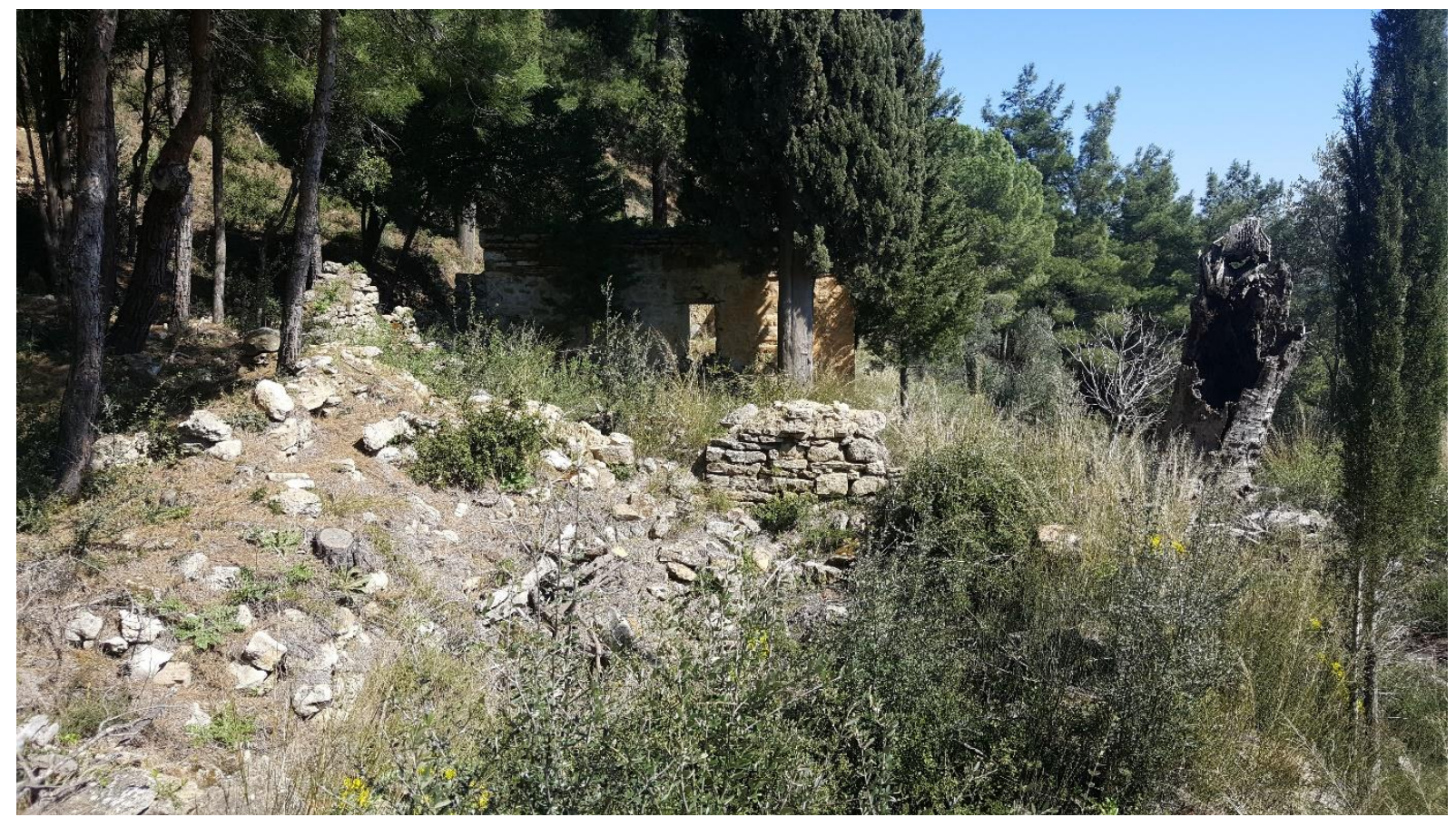

Türbe yapısının batı tarafında kalan bina yapılarının kalıntıları. Bu kalıntılar fotoğrafın çekildiği noktanın arkasına doğru devam etmektedir. Ancak arazi yapısı nedeniyle daha geniş açıdan fotoğraf çekilememiştir. 


\section{EK 12}

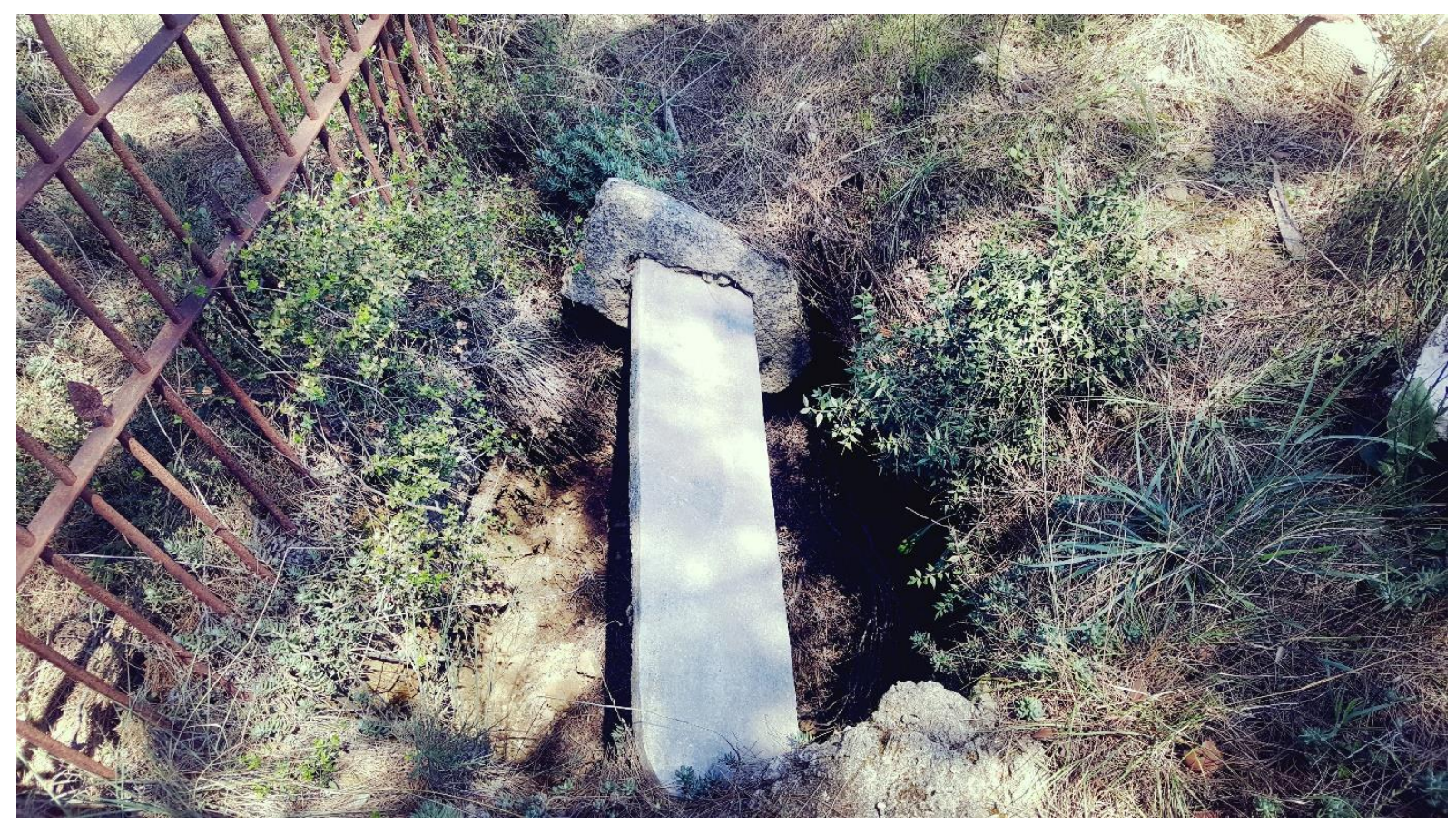

Tekke haziresindeki kaçak kazılara bir örnek.

\section{EK 13}

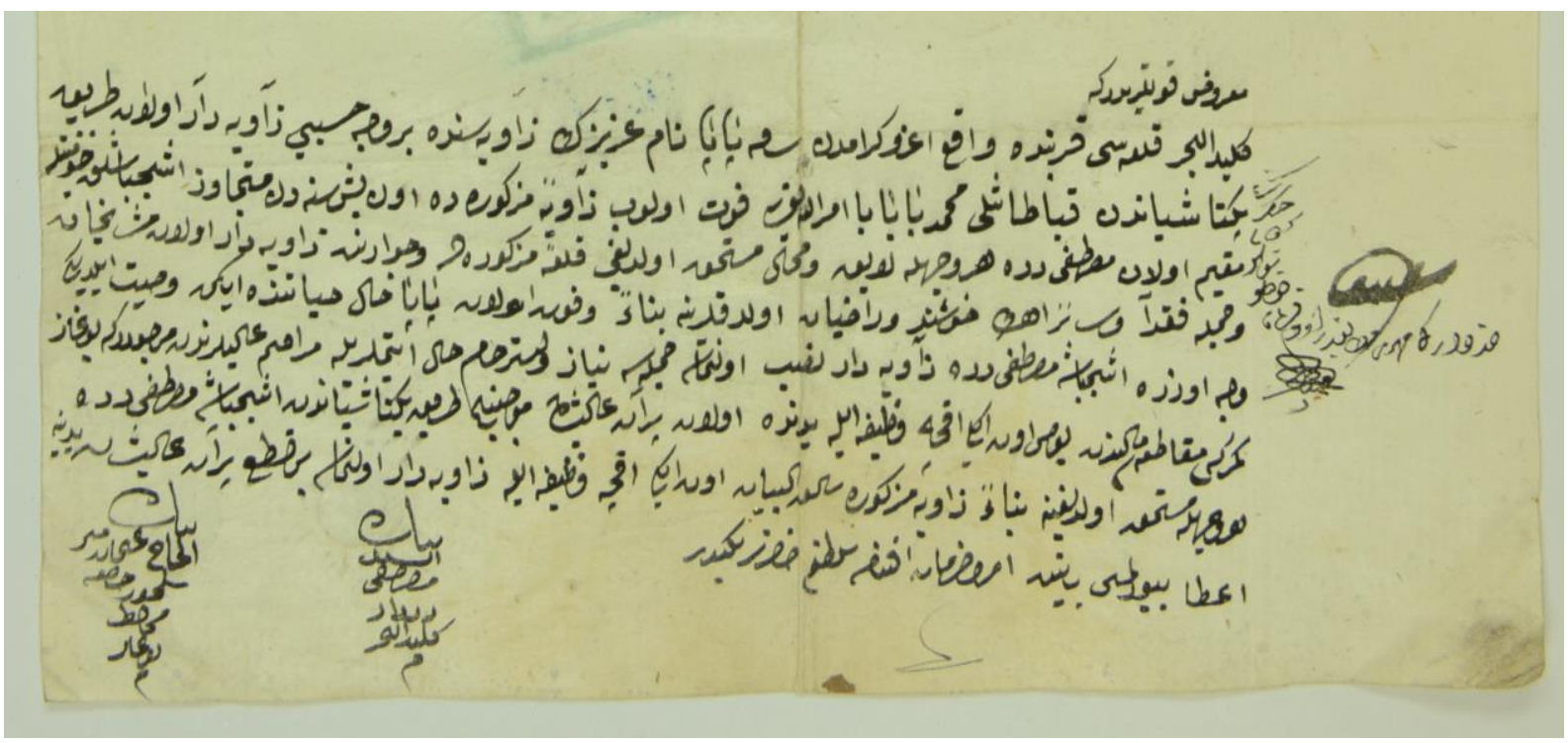

Saka Baba Dergâhına zâviye-dâr tayini ilgili belge görüntüsü 


\section{EK 14}

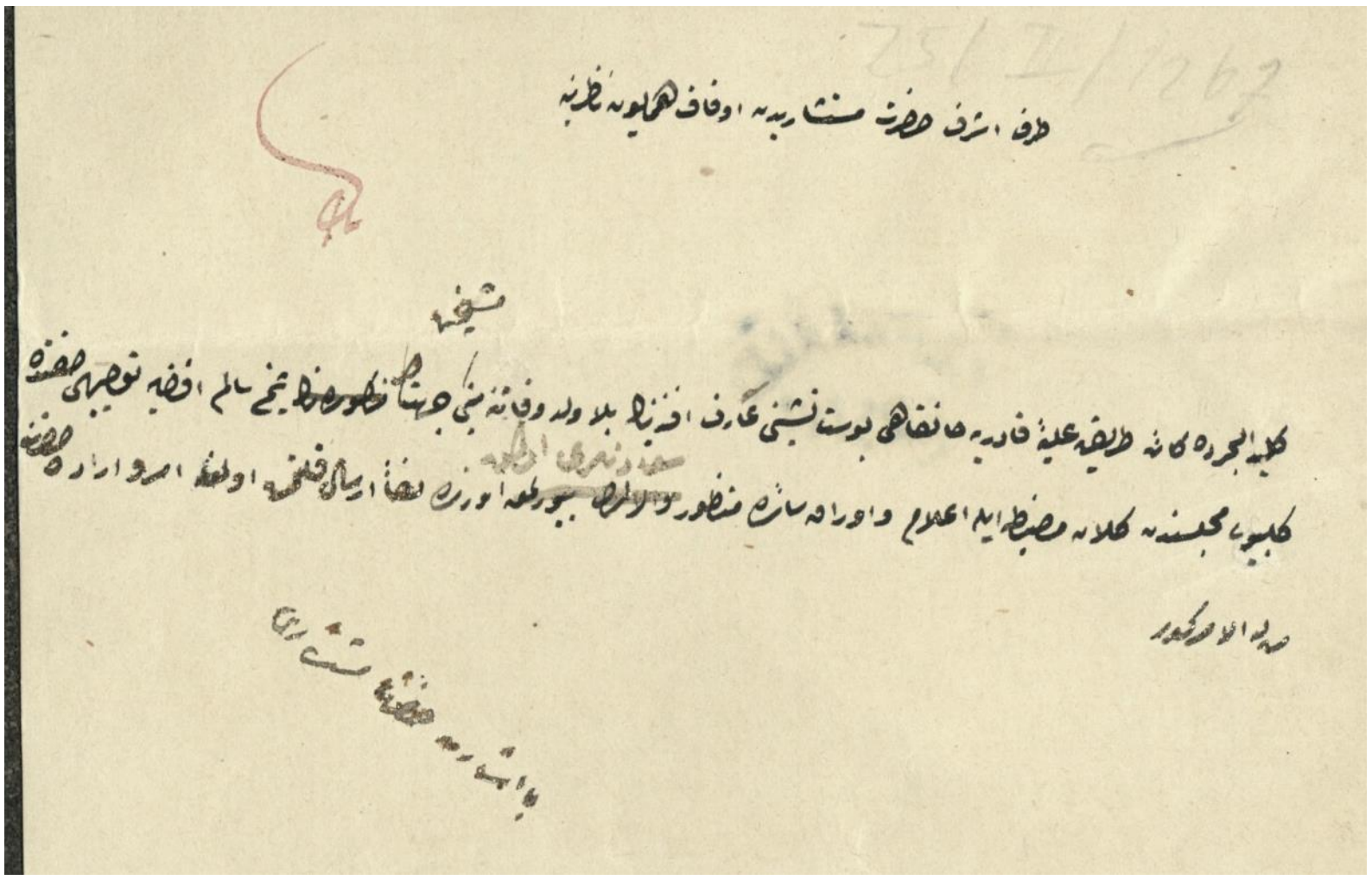

Arif Efendi'nin yerine Şeyh Salim Efendi'nin tayini ile ilgili belge görüntüsü

\section{EK 15}

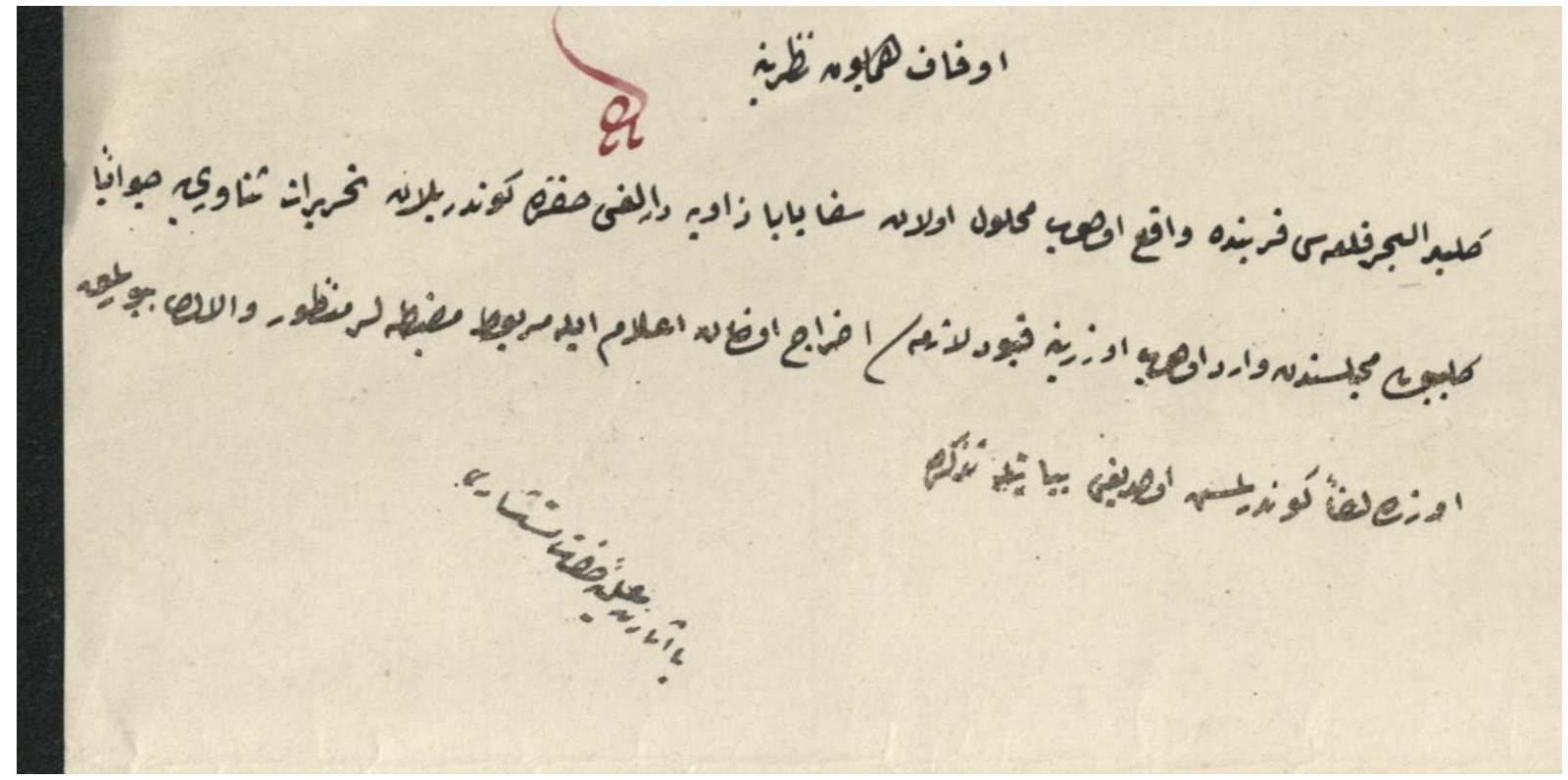

Kilitbahir Kalesi yakınındaki, Saka Baba Zaviyesi hakkındaki tahriratın takdimi ile ilgili belge görüntüsü 


\section{EK 16}

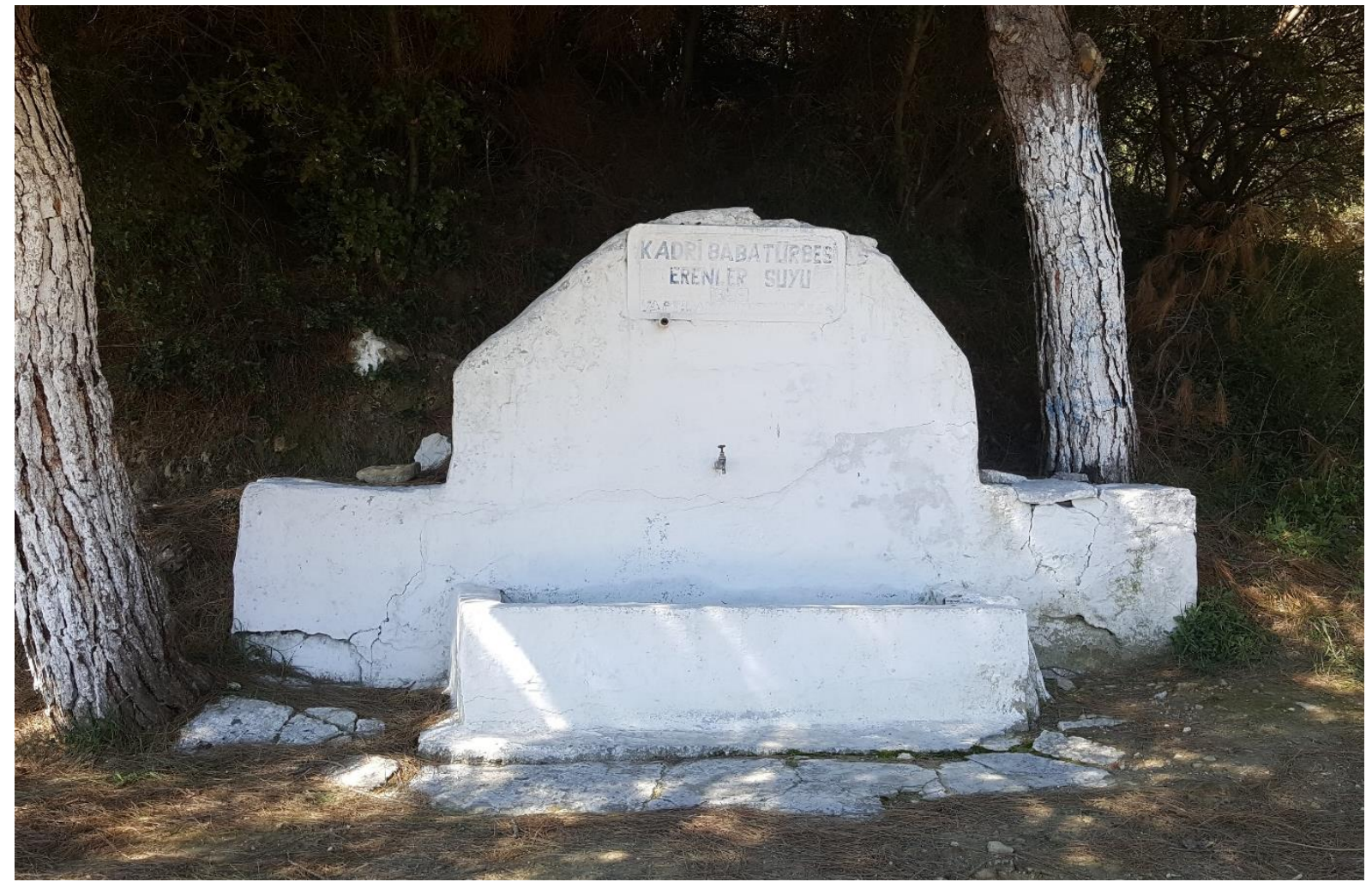

Saka Baba Dergâhı'nın alt kısmında yol kenarında yer alan çeşmesi

EK 17

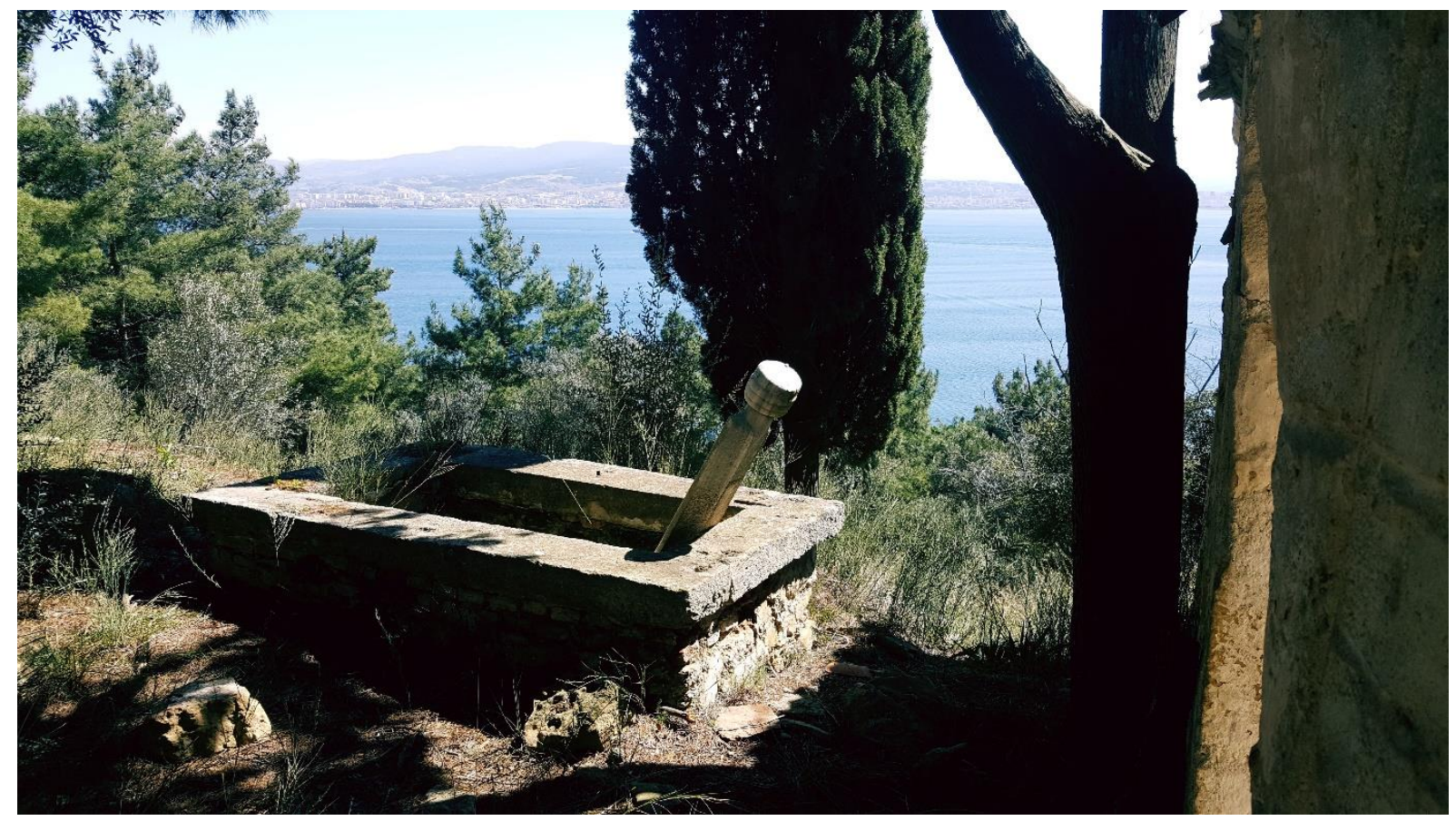

Saka Baba Dergâhı'ndan Çanakkale Boğazı Manzarası 